
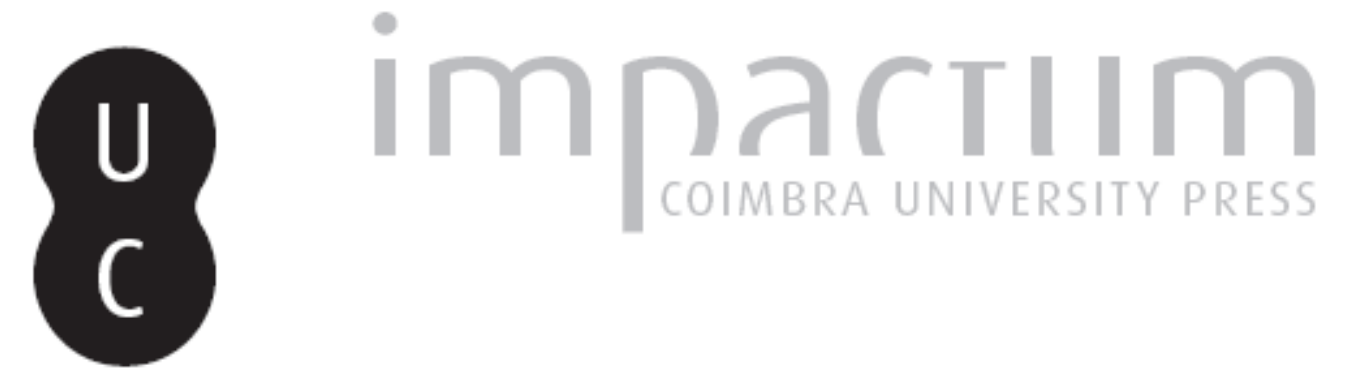

\title{
Fornos de ânforas de Alcácer do Sal
}

Autor(es): $\quad$ Diogo, A. M. Dias; Faria, João Carlos; Ferreira, Marisol A.

Publicado por: Imprensa da Universidade de Coimbra

URL persistente:

URl:http://hdl.handle.net/10316.2/45598

DOI:

DOI:https://dx.doi.org/10.14195/1647-8657_26_4

Accessed : $\quad$ 26-Apr-2023 14:12:15

A navegação consulta e descarregamento dos títulos inseridos nas Bibliotecas Digitais UC Digitalis, UC Pombalina e UC Impactum, pressupõem a aceitação plena e sem reservas dos Termos e Condições de Uso destas Bibliotecas Digitais, disponíveis em https://digitalis.uc.pt/pt-pt/termos.

Conforme exposto nos referidos Termos e Condições de Uso, o descarregamento de títulos de acesso restrito requer uma licença válida de autorização devendo o utilizador aceder ao(s) documento(s) a partir de um endereço de IP da instituição detentora da supramencionada licença.

Ao utilizador é apenas permitido o descarregamento para uso pessoal, pelo que o emprego do(s) título(s) descarregado(s) para outro fim, designadamente comercial, carece de autorização do respetivo autor ou editor da obra.

Na medida em que todas as obras da UC Digitalis se encontram protegidas pelo Código do Direito de Autor e Direitos Conexos e demais legislação aplicável, toda a cópia, parcial ou total, deste documento, nos casos em que é legalmente admitida, deverá conter ou fazer-se acompanhar por este aviso.

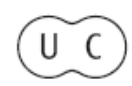


FACULDADE DE LETRAS

INSTITUTO DE ARQUEOLOGIA

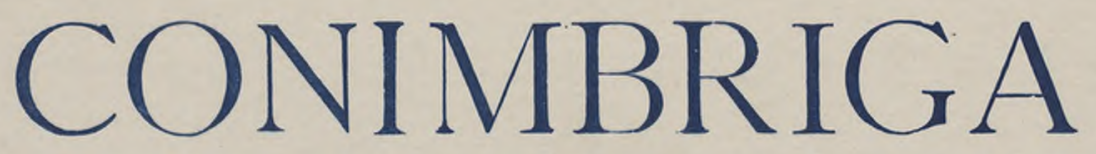

VOLUME XXVI

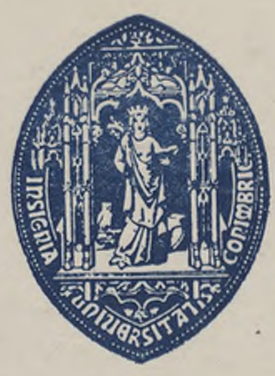

UNIVERSIDADE DE COIMBRA

1987 
A. M. Dias Diogo

Assistente da Universidade Nova de Lisboa

J0ÃO CARLOS FARIA

Director do Museu Municipal de Alcácer do Sal

MARISOL A. FERREIRA

Lie. em História/Arqueologia pela Fac. de Letras de Coimbra

FORNOS DE ÂNFORAS DE ALCÁCER DO SAL

«Conimbriga», XXVI (1987), p. 77-111.

Resumo: Estuda-se material proveniente de vários centros romanos de produção cerâmica nas margens do rio Sado. Trata-se de fornos fundamentalmente ligados à indústria de preparação do garum e de conservas de peixe e ainda, possivelmente, à produção de vinho.

SUMmARY : The AA. give notice and publish more material from the amphora Kilns in the Sado estuary. 
(Página deixada propositadamente em branco) 


\section{FORNOS DE ÂNFORAS DE ALCÁCER DO SAL}

Fornos de ânforas de Alcácer do Sal. Notícia preliminar

Situado junto à estrada que liga a vila de Alcácer à sua estação de caminho de ferro (coordenadas hectométricas: $156.1 \mathrm{~N}$., 166.2 E., na Carta Militar 1:25.000, folha . $^{\circ}$ 476), o forno que é objecto da presente notícia foi parcialmente destruído, há vários anos, pela extracção de areia realizada na escarpa que limita a sul a necrópole do Senhor dos Mártires. Dele apenas actualmente está à vista parte da parede circular da fornalha, construída com lateres e de cerca de $14 \mathrm{~cm}$. de espessura.

Geologicamente, a formação do local é do Miocènico médio, com conglomerados, biocalcorenitos mais ou menos gresosos e areias fossilíferas,, segundo a folha 39-C da Carta Geológica de Portugal.

Os fragmentos de ânfora encontrados junto a este forno pertencem ao tipo Dressel 14/Beltrán IV (est. I, n. ${ }^{\text {os }} 1$ a 6). Até ao momento, todos os bordos recolhidos são de secção triangular, com a aresta bem marcada, face superior convexa e claros vestígios de assentamento. $\mathrm{O}$ diâmetro da boca varia entre os $17 \mathrm{~cm}$. (n. $\left.{ }^{\circ} 4\right)$ e os 19,6 cm. (n. ${ }^{\circ} 3$ ). As asas são, naturalmente, de fita, bilobadas por um profundo sulco central e nascendo do terço superior do colo. Os bicos fundeiros são ocos, terminando em glande e com a superfície interior em forma de bola. Ambos os fundos aqui publicados (n. ${ }^{\text {ss }} 5$ e 6) têm marcas de controle, esgrafitadas na pasta ainda húmida, quando a ânfora se encontrava apoiada sobre a boca. A marca da n. $^{\circ} 5$ é comum a outros fornos : uma simples cruz, tendo primeiro sido gravado o traço horizontal, da esquerda para a 
direita, e seguidamente o traço vertical, de cima para baixo. A marca do fundo $n .^{\circ} 6$ encontra-se incompleta, apenas restando um traço oblíquo.

A pasta é dura, compacta, de aspecto folheado, com muitos pequenos quartzos hialinos e esbranquiçados e grande abundância de pequeníssimas micas. As tonalidades das pastas variam entre o bege e o laranja-avermelhado, mas são homogéneas dentro de cada vaso. As superfícies exteriores são rugosas e foram alisadas a trapo ou a pincel. Os fragmentos n.os 1 e 5 têm vestígios de um engobe acastanhado.

Também o fragmento $\mathrm{n} .{ }^{\circ} 7$, um pequeno pote com o bordo em forma de aba, revirado para fora e dobrado sobre os ombros, foi encontrado junto ao forno. Embora mais fina, a pasta é semelhante à das ânforas, assim como o engobe, de tonalidade acastanhada. Diâmetro da boca: $13,4 \mathrm{~cm}$.

Junto à mesma estrada, mas a cerca de duzentos metros mais próximo de Alcácer, observa-se, no pequeno barranco que no lado norte bordeja o caminho, um muro de pedras e uma parede circular de lateres. Esta estrutura deve corresponder a um outro forno, o que parece ser confirmado pela argila calcinada que rodeia os lateres. Por outro lado, sabemos que os fornos do vale do Sado não funcionavam em unidades isoladas, mas em complexos, o que evidentemente tornava mais rendível a sua exploração económica. Aponte-se ainda que, acima do pequeno barranco já referido, existe um patamar que se estende por um largo troço da estrada e que muito bem pode corresponder ao nível da grelha de uma série de fornos.

De junto a esta estrutura são provenientes os nossos fragmentos n.os 8 e 9. O primeiro é de fabrico local, um bordo de ânfora Dressel 14/Beltrán IV, com o bordo de secção triangular da variante com ressalto, a dar-lhe o aspecto de um bordo de fita. A pasta é semelhante à dos exemplares anteriores e está coberta com um engobe acastanhado. Diâmetro do bordo: 19,2 cm.

O exemplar $n .{ }^{\circ} 9$ é um fragmento de boca de ânfora de tipo Dressel 20/Beltrán V. O lábio é de perfil triangular, achatado. A pasta é dura, fina, com areias e fendas muito pequenas e de tonalidade bege. Sem vestígios de engobe. Diâmetro do bordo: $17 \mathrm{~cm}$. 
A ânfora Beltrán V é proveniente da Bética, de onde transportava azeite e azeitonas. Cronologicamente, o seu fabrico situa-se entre Augusto e meados do séc. m. O perfil do lábio do nosso exemplar aponta para uma datação que não ultrapassará a segunda metade do séc. i.

Sensivelmente a meia distância das duas estruturas anteriormente noticiadas e ainda no pequeno barranco junto à estrada, encontram-se dois lateres que, a estarem in situ, poderão corresponder a um pavimento.

O material dos fornos romanos de Arapouca no Museu Municipal de Alcácer do Sal.

Situados numa pequena encosta arenosa a cerca de $70 \mathrm{~m}$. da margem esquerda do Sado, e a $6 \mathrm{~km}$ para montante de Alcácer do Sal, estes fornos têm as coordenadas de 149,7 N. e 168,6 E., segundo a Carta Militar 1:25.000, folha n. ${ }^{\circ} 486$ (l).

São possivelmente em número de dois, de planta circular e formados com lateres vulgares. Um dos fornos foi muito danificado pela construção de uma vala de rega; o seu diâmetro interno é de cerca de $3,10 \mathrm{~m}$ e as paredes têm a espessura de $0,45 \mathrm{~cm}$. Próximo dos fornos apareceram outros vestígios romanos, como fragmentos de sigillata sudgálica e opus signinum.

Seriam talhas o único tipo de vasilhame que estes fornos aparentam ter fabricado. Já tinha sido notado o seu fabrico em outros fornos do Sado (2), e deveriam ter sido utilizados para o armazenamento e transporte de algum produto agrícola originário das margens do rio. Os fragmentos recolhidos, depositados no Museu Municipal de Alcácer (Est. II), apontam para um fundo raso, em bolacha, (diâmetro de $26 \mathrm{~cm}$ no n. ${ }^{\circ}$ ), um bojo ovoide

I1) João C. Lázaro FARIA e Marisol A. FERreira, Estações inéditas da época romana do Concelho de Alcácer do Sal - Breve notícia, "Conimbriga», 25, 1986, p. 47-48.

(2) Veja-se A. M. Dias Diogo et alii, $O$ material dos fornos romanos da Enchurrasqueira no Museu do Mar, «Série Arqueológica», Vol. 1, Sep. 3, Cascais, 1984. 
com asas semicirculares, de fita, largas, bilobadas por um sulco central. $\mathrm{O}$ bordo apresenta perfis variáveis mas fundamentalmente resultantes do engrossamento da parede no remate, obtido através da dobra para o exterior (diâmetros internos: $1-32 \mathrm{~cm}$., $2-26,8 \mathrm{~cm} ., 3-28 \mathrm{~cm}$.).

A pasta é homogénea, de tonalidades alaranjadas ou ocres, aspecto folheado, relativamente fina, com pequenas areias bem disseminadas e com micas.

Superfícies irregularmente alisadas, tendo a exterior levado uma aguada, o que a torna de tonalidade ligeiramente mais escura do que a pasta $\left({ }^{3}\right)$.

Ânforas dos fornos do Bugio II no Museu Municipal de Alcácer do Sal

Os fornos de ânforas do Bugio II estão situados na margem direita do rio Sado, a cerca de $750 \mathrm{~m}$ para jusante dos fornos do Bugio I $\left({ }^{4}\right)$. Chegaram a ser por nós chamados de forno 4 do Bugio*(5). $\mathrm{O}$ facto de estarem relativamente distantes destes últimos fornos e de, aparentemente, não haver entre eles quaisquer vestígios romanos levou-nos a chamá-los agora de Bugio II.

Coordenadas hectométricas : 159,5 N., 164,5 E., segundo a Carta Militar 1:25.000, folha n. ${ }^{\circ} 476$.

No que respeita a ânforas, estes fornos apenas devem ter produzido o tipo Dressel 14. Não há ainda evidência para o fabrico de outro tipo de vasos.

(3) Sobre o uso de talhas para o transporte, possivelmente do vinho, por via marítima, veja-se: Des bateaux citernes: les épaves romaines à dolia no catálogo da exposição de Nantes, em 1985, Archéologie sous-marine sur les côtes de France. Vingt ans de recherche, p. 79-81.

$\left.{ }^{4}\right)$ Antonio M. Dias Diogo, Fornos de ânforas do Monte do Bugio. Notícia preliminar, «Conimbriga», 19, 1980, p. 147-150.

${ }^{5}$ ) A. M. Dias Diogo, Fornos de ânforas do Monte da Enchurrasqueira e do Vale da Cepa. Notícia preliminar, «Conimbriga», 22, 1983, p. 209-215, nota 4. 
Dos 19 bordos de Dressei 14 que o Museu de Alcácer possui, provenientes de recolhas feitas por João C. Lázaro Faria, sete $(36,8 \%)$ inscrevem-se na variante de bordo perolado, com o colo quase vertical, o diâmetro da boca varia entre os 17 e os $19 \mathrm{~cm}$., sendo a média de cerca de $18 \mathrm{~cm}$. (Est. Ill, n.os 4 e 5). Onze (Est. Ill, n. os 1 e 2, 57,9\%), na de bordo subtriangular, com a face superior convexa e com um ressalto a dar-lhes o aspecto de bordo de fita. O colo destas últimas é côncavo, esvasado junto ao lábio; o diâmetro da boca varia entre os 17 e os $20 \mathrm{~cm}$., sendo a média de cerca de $18,2 \mathrm{~cm}$. Um exemplar (Est. Ill, n. ${ }^{\circ}$ 3), tem o lábio com um perfil pouco comum. O colo é côncavo, esvasado junto ao lábio, que é muito engrossado, de perfil subtriangular e aresta muito vincada, tem um ressalto muito nítido a apenas cerca de $3 \mathrm{~cm}$. da boca, formando um lábio bem marcado e diferenciado do colo. Diâmetro da boca $17 \mathrm{~cm}$.

No que respeita aos fundos, o Bugio II apresenta-nos a variante em glande, com o interior preenchido por uma bola de argila. Os dois bicos fundeiros que publicamos (Est. Ill, n. ${ }^{\text {os }} 6$ e 7) têm marcas invertidas, esgrafitadas quando a ânfora se encontrava a secar, apoiada sobre a boca. $\mathrm{O}$ grafito da $\mathrm{n} .{ }^{\circ} 6$ é um «B», e surgiu-nos em três exemplares; o da $n .^{\circ} 7$ é por enquanto único, e tem a forma de um «Z», num fundo de glande muito pronunciada.

O tratamento das superfícies externas das ânforas é simplesmente alisado, muito provavelmente a pincel. A pasta é semelhante à dos outros fornos do Sado, na sua variante micácea e com muitas inclusões ferruginosas.

Materiais dos fornos romanos da Barrosinha II no Museu Municipal de Alcácer do Sal

Embora conhecidos desde finais do século passado (Joaquim Correia Baptista, 1896, p. 7), os fornos da Herdade da Barrosinha nunca foram sujeitos a qualquer publicação monográfica. Guardamos para outro estudo os fornos já conhecidos por Correia Baptista, que designamos por Barrosinha I (Foto 1,1) e cujo material se encontra disperso por várias instituições. 
84 A. M. Diogo, J. c. FARiA, M. Ferreira, Fomos de Anforas de Alcacer do Sal

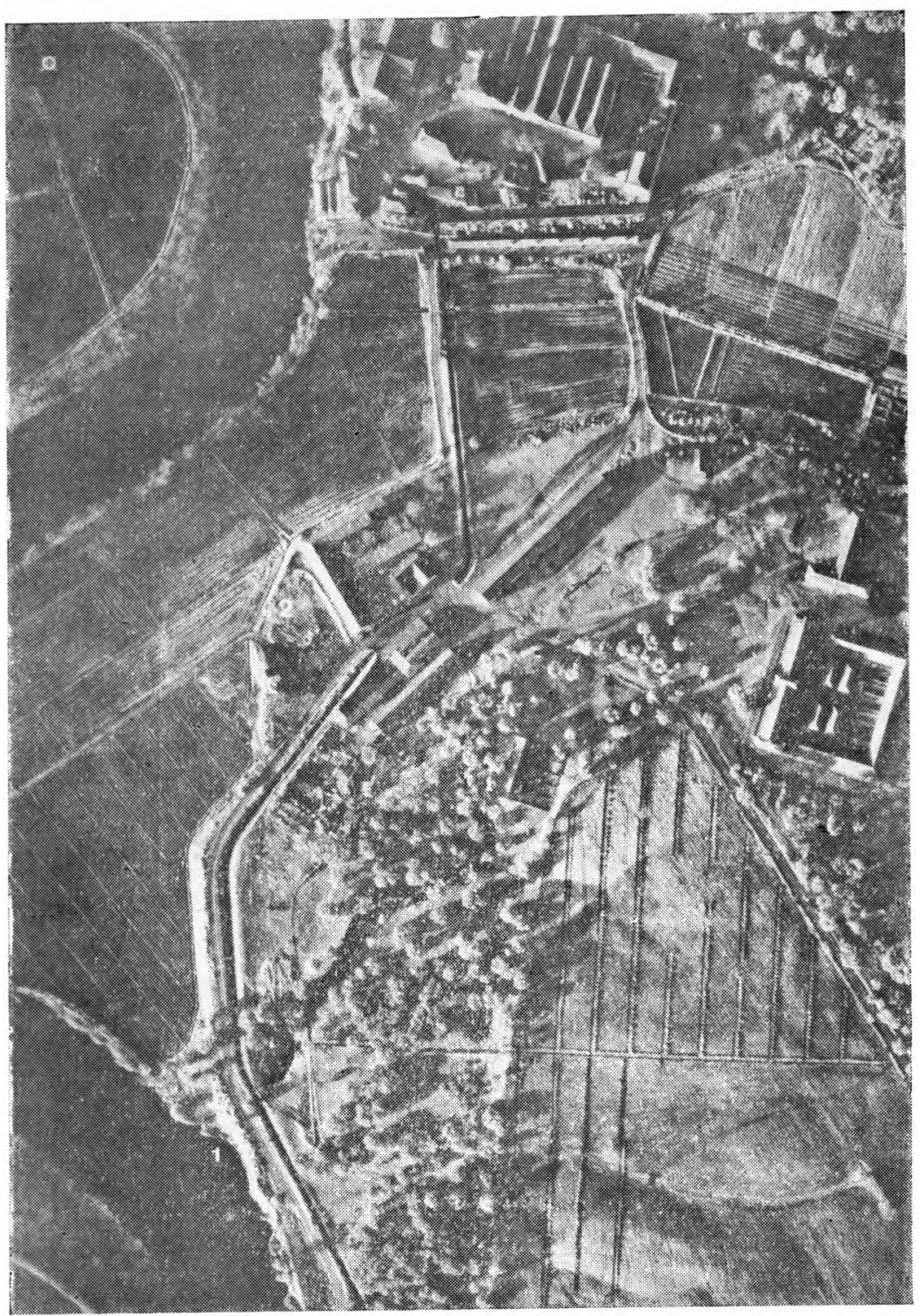

Foтo 1. - Fotografia aérea da Barrosinha

Conimbriga, 26 (1987), 67-111 
A Herdade da Barrosinha fica situada junto ao rio Sado, a cerca de 2,5 km para montante de Alcácer do Sal. O material agora estudado foi recolhido no Verão de 1978 pelos autores e ainda por Fernando Gomes ${ }^{6}$ ), de uma vala aberta para o escoamento de águas, e foi depositado no Museu Municipal de Alcácer do Sal. A vala, hoje já tapada e então recentemente aberta (Foto 1,2), tinha as coordenadas hectométricas de 154.8 N., 169.4 E., na Carta Militar 1:25.000, folha 477.

Tendo fabricado ânforas de tipo Dressel 14 e grande variedade de cerâmica comum, de pasta e fabrico muito semelhantes às dos outros fornos do Sado, estes caracterizam-se, no entanto, pela grande escassez de mica que parece inexistente à vista desarmada. O material de fabrico local encontrava-se misturado com o importado, numa camada compacta, permitindo datar a produção de cerca de Cláudio até, talvez, aos inícios do séc. n. De notar a identidade do material aqui estudado com o encontrado na camada de abandono da ocupação significativa da Alcácer romana (Tavares da Silva et alii, 1980-81, p. 189 e s.).

\section{Anforas}

No que respeita a ânforas, os fornos da Barrosinha apenas aparentam ter produzido o tipo Dressel 14/Beltrán IV. Do total de 17 bordos que o Museu de Alcácer possui da Barrosinha II, 6 são do tipo perolado (Est. IV, 6) e 11 do tipo triangular $(35,3 \%$ e $64,7 \%)$. Dentro deste segundo tipo, aparece-nos sobretudo a variante com ressalto, a dar-lhes o aspecto de bordo de fita (Est. IV, 2-5). $\mathrm{O}$ diâmetro da boca varia entre os 16 e os $22 \mathrm{~cm}$., sendo a média de $19 \mathrm{~cm}$.

O fabrico e a pasta destas ânforas são semelhantes aos dos outros fornos do Sado. A pasta é dura, com fendas abundantes que the dão um aspecto folheado. Os elementos não-plásticos são muito abundantes, predominando o quatrzo esbranquiçado de tamanho inferior a $1 \mathrm{~mm}$. As inclusões negras e os quartzos grandes, atin-

(6) A quem se devem ainda as fotografias 2 e 3. 
gindo os $4 \mathrm{~mm}$, são escassos. A tonalidade da pasta é uniforme dentro de cada vaso, sendo geralmente alaranjada.

As superfícies são ásperas, pouco mais escuras do que a pasta, e alisadas a trapo ou a pincel.

Apareceram-nos nestes fornos 31 exemplares de várias variantes da mesma marca de oleiro T.M.C. $\left({ }^{7}\right)$. Impressa em carteia rectangular (41 X $16 \mathrm{~mm}$ na $n .{ }^{0 i} 9,36 \times 18 \mathrm{~mm}$ na.$\left.^{\circ}{ }^{\circ} 10\right)$, encontra-se normalmente sobre a asa esquerda (17 exemplares), embora também possa surgir na asa direita. Apenas em dois exemplares sobre as asas ela não nos aparece invertida. Dois fragmentos apresentam uma marca, não-invertida, sobre a pança, junto ao arranque da asa (n. $\left.{ }^{\circ} 10\right)$.

Marcas esgrafitadas, de controlo do fabrico, apenas nos surgiram no bico fundeiro (.$^{\circ}$ 11-19), não havendo ainda evidência para as do fundo da pança. Como é normal, são invertidas por terem sido feitas quando a ânfora se encontrava com a boca assente no chão. Como variante, note-se que aqui nos surgem grafitos desenhados no próprio fundo do bico fundeiro (n. $\left.{ }^{\text {os }} 14-19\right)$.

A maioria dos bicos fundeiros tem a face interna em forma de bola, que na verdade é devida à introdução de uma bola de argila no bico, de modo a torná-lo mais resistente, e devem, por isso, ser posteriores aos de bico oco (n. ${ }^{\text {os }} 11$ e 13$)$.

\section{Anforas importadas}

As ânforas n.os 20 e 21 (Est. IV) são importadas. A 20 inclue-se no tipo Beltrán IIB, fabricada na Bética, é datável de Augusto aos finais do séc. $\mathrm{n}$ e transportaria produtos de origem piscícola. A n. ${ }^{\circ} 21$ é, muito provavelmente, proveniente do sul de Espanha e poderá ser genericamente incluída na forma Beltrán I, em que este autor agrupou as Dressel 7-11. É datável da segunda metade do séc. i a. C. e de todo o séc. i.

(7) E não D.M.I, como foi publicado em Diogo, 1980, p. 147. A relacionação entre o gentilicio desta marca e o da marca encontrada nos fornos de Barrosinha I (MA.MV.S) será feita noutro trabalho, em preparação. 
20. (Est. IV, n. 1652). Fragmento de boca de ânfora, de lábio pendente. Diámetro da boca $22 \mathrm{~cm}$.

Pasta branda, pulverulenta e muito fina, pequeníssimos alvéolos e micas, inclusões negras e ocres, de tonalidade bege. Sem vestígios de engobe.

21. (Est. IV, n. 1518). Fragmento de boca de ânfora; lábio de fita, em forma de feijão, com um ressalto a separá-lo do colo. Diâmetro da boca $18 \mathrm{~cm}$.

Pasta dura, granulosa, com pequenas areias roladas, de tonalidade laranja-acastanhada, Superfície de tonalidade rosa, alisada na superfície exterior.

\section{Cerâmica comum}

É relativamente abundante e variada a cerâmica comum recolhida da vala. Geralmente de tonalidades alaranjadas, de pastas semelhantes às das ânforas (embora mais finas) e superfícies externas simplesmente alisadas, sem engobes, deixam facilmente transparecer o seu fabrico local.

22. (Est. V, n. ${ }^{\circ}$ 708). Pote Bordo revirado para fora e arqueado, ombros quase rectos a sugerirem um bojo ovoide.

Diâmetro $16 \mathrm{~cm}$.

23. (Est. V, n. 1658). Idem.

Diâmetro $17 \mathrm{~cm}$.

24. (Est. V, n. ${ }^{\circ}$ 1492) Pote. Bordo oblíquo ligeiramente côncavo no dorso, ombros arredondados. Pasta bege-acinzentada.

Diâmetro $14 \mathrm{~cm}$.

25. (Est. V, n. $\left.{ }^{\circ} 1568\right)$ Idem.

Diâmetro $13 \mathrm{~cm}$.

26. (Est. V, n. $\left.{ }^{\circ} 1659\right)$ Idem.

Diâmetro $16 \mathrm{~cm}$.

27. (Est. V, n. $\left.{ }^{\circ} 1496\right)$ Idem.

Diâmetro $15 \mathrm{~cm}$.

28. (Est. V, n. $\left.{ }^{\circ} 1566\right)$ Idem, com vestígios de asa de fita a nascer da sobeira do bordo.

Diâmetro $13 \mathrm{~cm}$.

29. (Est. V, n. ${ }^{\circ}$ 1576) Idem.

Diâmetro $7 \mathrm{~cm}$.

Conimbriga, 26 (1987), 77-111 
30. (Est. $\mathrm{V}, \mathrm{n} .^{\circ}$ 1445) Tacho. Bordo em aba grossa, corpo possivelmente ovoide truncado.

Diâmetro $24 \mathrm{~cm}$.

31. (Est. y, n. ${ }^{\circ}$ 1479) Idem.

Diâmetro $24 \mathrm{~cm}$.

32. (Est. $\mathrm{V}, \mathrm{n} .^{\circ}$ 1474) Idem.

Diâm. $30,5 \mathrm{~cm}$.

33. (Est. V, $\mathrm{n}^{\circ}$ 973) Idem. Corn largo cerne acinzentado.

Diâmetro $32 \mathrm{~cm}$.

34. (Est. Y, n. ${ }^{\circ}$ 477) Idem.

Diâmetro $28 \mathrm{~cm}$.

35. (Est. VI, n. ${ }^{\circ}$ 1480) Pequeno tacho? Bordo em forma de gancho engrossado, bojo possivelmente ovoide alto.

Pasta ocre, branda, de aspecto terroso. Superfície externa muito alisada.

Diâmetro $15 \mathrm{~cm}$.

36. (Est. V, n. ${ }^{\circ}$ 709) Panela. Bojo ovoide largo e baixo, bordo em abaDiâmetro $23 \mathrm{~cm}$.

37. (Est. V, n. ${ }^{\circ}$ 712) Idem.

Diâmetro $24 \mathrm{~cm}$.

38. (Est. $\mathrm{V}, \mathrm{n} .^{\circ}$ 1494) Idem. Bordo em cabeça de martelo, descaído. Diâmetro $28 \mathrm{~cm}$.

39. (Est. V, n. ${ }^{\circ}$ 1481) Taça? Bordo em gancho, paredes esvasadas, carena alta e vincada.

Pasta mal cozida, de textura folheada, branda, com pequenas areias, cinzento-esverdeada com cerne cinzento-claro.

Diâmetro $30 \mathrm{~cm}$.

40. (Est. VI, n. ${ }^{\circ}$ 1487) Prato covo, bordo em aba direita, paredes arqueadas.

Diâmetro $28 \mathrm{~cm}$.

41. (Est. VI, n. ${ }^{\circ}$ 974) Idem. Bordo em pingo, paredes muito divergentes.

Diâmetro $31 \mathrm{~cm}$.

42. (Est. VI, n. ${ }^{\circ}$ 1567) Alguidar. Troncocònico, bordo em aba curva. Diâmetro $30 \mathrm{~cm}$.

43. (Est. VI, n. ${ }^{\circ}$ 976) Bacia? Parede quase vertical, bordo em aba pendente.

Diâmetro $38 \mathrm{~cm}$.

44. (Est. VI, n. ${ }^{\circ}$ 711) Grande tigela? Parede arqueada, bordo simples, com engrossamento interno.

Pasta rosada.

Diâmetro $40 \mathrm{~cm}$.

45. (Est. VI, n. ${ }^{\circ}$ 717) Tigela? Paredes esvasadas e bordo simples boleado.

Diâmetro $16 \mathrm{~cm}$. 
46. (Est. VI, n. ${ }^{\circ}$ 1654) Idem. Parede arqueada e bordo simples, boleado. Diâmetro impossível de calcular.

47. (Est. VI, n. ${ }^{\circ}$ 970) Tigela? Copa arqueada, pé anelar. Pasta cinzento-clara, micácea e arenosa. Superfícies mais negras. Diâmetro do fundo $6,6 \mathrm{~cm}$.

48. (Est. VI, n. ${ }^{\circ}$ 1495) Pequeno tacho? Parede vertical, bordo em pequena aba curva.

Diâmetro $16 \mathrm{~cm}$.

49. (Est. VI, n. ${ }^{\circ}$ 1574) Pequeno tacho? Parede vertical, bordo em curta aba horizontal, de dorso reentrante.

Diâmetro $16 \mathrm{~cm}$.

50. (Est. VI, n. ${ }^{\circ}$ 1573) Panela. Colo oblíquo e bordo em aba, espessado dos dois lados.

Diâmetro $18 \mathrm{~cm}$.

51. (Est. VII, n. ${ }^{\circ}$ 975) Pratel. Parede arqueada, quase carenada, bordo em aba arqueada.

Diâmetro $19 \mathrm{~cm}$.

52. (Est. VI, n. ${ }^{\circ}$ 757) Bilha. Bordo em banda, rectangular, boleado. Colo largo, sobre o cilíndrico, ombros arredondados, asas de fita nascendo da sobeira do bordo.

Diâmetro $13 \mathrm{~cm}$.

53. (Est. VI, n. ${ }^{\circ}$ 971) Talha. Bordo engrossado, corpo possivelmente ovoide.

Diâmetro interno da boca $31 \mathrm{~cm}$.

54. (Est. VI, n. ${ }^{\circ}$ 739) Idem. Bordo ligeiramente engrossado e canelado, corpo possivelmente ovoide.

Pasta bege, com largo cerne cinzento-esverdeado, micácea, com areias atingindo $1 \mathrm{~cm}$.

55. (Est. VII, n. ${ }^{\circ}$ 737) Tampa circular de ânfora, com pegadeira central perfurada para montagem do opérculo.

Superfície exterior bege, interior laranja-amarelada.

Diâmetro máximo $9,2 \mathrm{~cm}$. Altura $3,1 \mathrm{~cm}$.

56. (Est. n. ${ }^{\circ}$ 759) Idem.

Pasta branda, de textura folheada, arenosa de pequeno grão, atingindo ocasionalmente os $2 \mathrm{~mm}$. Micácea, com nódulos ferruginosos.

Superfícies beges.

Diâmetro máximo 9,4 cm. Altura 2,9 cm.

57. (Est. VII, n. ${ }^{\circ}$ 730) Testo de forma troncocònica e bordo boleado. Superfície interna mais rugosa.

Diâmetro $22 \mathrm{~cm}$. 
90 A. M. Diogo, J. c. Faria, M. Ferreira, Fornos de Ânforas de Alcácer do Sal

58. (Est. VII, n. ${ }^{\circ}$ 1567) Idem.

Bege, com manchas cinzentas da cozedura.

Diâmetro $21 \mathrm{~cm}$.

59. (Est. VII, n.o 1500) Idem.

Pasta cinzenta, queimada no forno.

Diâmetro impossível de calcular.

Telhas

Foram recuperados dois fragmentos de telhas (tegulae). Ambas com o bordo em meia-cana elas são, no entanto, de fabricos muito distintos.

60. (Est. VI, n. ${ }^{\circ}$ 1560) Pasta semelhante à das ânforas, embora mais micácea, com areias atingindo os $0,4 \mathrm{~cm}$. Tonalidade alaranjada. Altura do bordo 6,3 cm. Altura do corpo 2,7 cm.

61. (Est. VI, n. ${ }^{\circ}$ 740) Pasta porosa, com fendas, alvéolos e nódulos alaranjados atingindo os $2 \mathrm{~cm}$. Tonalidade amarelada. Altura do bordo $6,5 \mathrm{~cm}$. Altura do corpo 2,7/3 cm.

Peso de tear

A peça n. $^{\circ} 62$ (Est. VII, n. ${ }^{\circ}$ 1470) é um fragmento de peso de tear vertical. Forma de paralelepípedo de secção sensivelmente quadrada $(4,4 \times 4,5 \mathrm{~cm}$ ao nível do furo), com um furo central troncocònico no topo. Tem uma marca gravada antes da cozedura na face superior, possivelmente um «C» (Est. X). Pasta semelhante à das ânforas, de tonalidade bege-alaranjada.

\section{Peso de rede}

A peça $n .^{\circ} 63$ (Est. VII, n. ${ }^{\circ}$ 1471) é um peso de rede, possivelmente romano. De forma anelar, apresenta um desgaste nas faces para a fixação. A pasta é de tonalidade alaranjada, com pequenas areias, micas e inclusões ocres.

Altura 2,1 cm. Largura 5,8/6,3 cm. 
A. M. Diogo, J. c. faria, M. ferreira, Fornos de Anforas de Alcácer do Sal 91

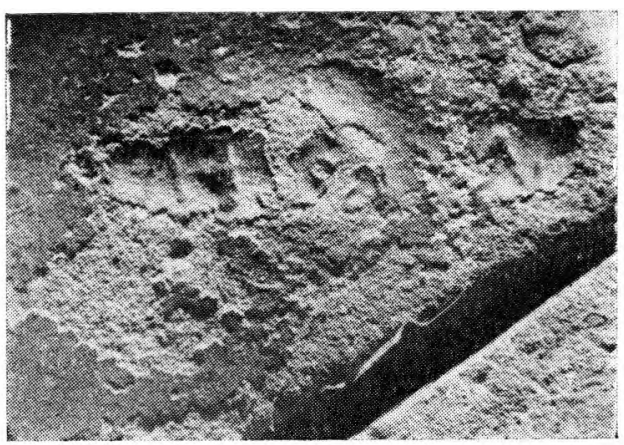

Fото 2. - Marca de M. IVLIVS SEVERVS

Conimbriga, 26 (1987), 77-111 
92 a. M. Diogo, J. c. Faria, M. ferreira, Fornos de Ânforas de Alcácer do Sal

\section{Terra sigillata}

Das sigillatas que estudamos, a n. ${ }^{\circ} 64$ é um prato de origem itálica, embora não aretino. Trata-se de uma forma Dragendorff 17, datável de Augusto-Tibério.

Os fragmentos 65 a 69 são sudgálicos. A taça n. ${ }^{\circ} 65$ é uma forma Dragendorff 27, conservando uma marca de oleiro $M$. IVLIVS SEVERVS, ainda sem paralelo registado em território português. Deverá ser proveniente de La Graufresenqne e datável de meados do séc. i.

Também da forma Dragendorff 27, uma das mais comuns em Portugal, é o vaso 66. O seu pequeno tamanho e o lábio sublinhado datam-no da época de Cláudio. $\mathrm{O}$ n. ${ }^{\circ} 67$ é uma taça de forma Ritterling 8. A taça 68 inclui-se na forma Drag. $24 / 25$ e é datável de Cláudio-Vespasiano.

O fragmento $\mathrm{n} .{ }^{\circ} 69$ pertence a um prato, possivelmente de forma Dragendorff 15/17. Tem uma marca de FELIX, oleiro de La Graufesenque e Montans, datável do período Cláudio-Nero, já atestado em Conimbriga.

O n. ${ }^{\circ} 70$ é de origem hispânica, uma forma Dragendorff 29, com o bojo decorado por círculos concêntricos e datável do terceiro quarto do séc. i.

A tigela 83 é uma sigillata clara A, forma 23 de Lamboglia, 6 de Hayes, a que infelizmente falta o fundo para podermos fazer uma classificação mais precisa. Originária do Norte de África, é datável dos fins do séc. i, inícios do $n$.

64. (Est. Vili n. ${ }^{\circ}$ 773) Prato de bordo direito e levemente esvasado.

Pasta muito fina, branda, de tonalidade ocre.

«Verniz» bem aderente, fino, homogéneo, brilhante, alaranjado.

Diâmetro da boca cerca de $19,8 \mathrm{~cm}$.

65. (Est. X e foto 2, n. ${ }^{\circ}$ 1650) Fragmento de taça, bordo vincado, arredondado, bojo em S, pé alto de perfil triangular.

Pasta laranja-avermelhada, dura, com calci tes pequenas e bem disseminadas.

«Verniz» avermelhado, de brilho mate, pouco aderente, fino e homogéneo.

Conserva uma marca no centro do fundo M. [IVL.] SEV em carteia rectangular com os ângulos arredondados $(2 \times 1,4 \mathrm{~cm})$.

Diâmetro do bordo $12 \mathrm{~cm}$. Diâmetro do pé $4,9 \mathrm{~cm}$. Altura $5,4 \mathrm{~cm}$. 
66. (Est. Vili, n. ${ }^{\circ}$ 768) Pequena taça, lábio bem sublinhado, bojo em S. Pasta rosada, dura, com pequeníssimas calcites.

«Verniz» vermelho-alaranjado, brilhante, aderente e homogéneo, com bandas de alisamento na superfície externa.

Diâmetro da boca $14 \mathrm{~cm}$.

68. (Est. Vili, n. ${ }^{\circ}$ 1600) Taça de bordo ligeiramente curvo e lábio arredondado, separado do bojo por um estribo e decorado com uma banda de guiloché fino.

Pasta dura, fina, com pequeníssimas calcites, rosada.

Diâmetro da boca $12,9 \mathrm{~cm}$.

69. (Est. X e foto 3, n. ${ }^{\circ}$ 761) Prato, pé de perfil de tronco-cónico, com larga superfície de sustentação. Fundo arqueado para o interior, com um ressalto a formar degrau.

Pasta vermelho-alaranjada, com muitas calcites e pequenas fendas. «Verniz» avermelhado, de brilho mate, fino e manchado, quebrado na superfície externa.

Conserva uma marca no centro do fundo OF FELICIS, bem estampada, em carteia rectangular de ângulos fortemente arredondados $(1,7 \times 0,35 \mathrm{~cm})$.

Diâmetro $10,2 \mathrm{~cm}$.

70. (Est. Vili, n. ${ }^{\circ}$ 1587) Taça, de bordo curvo e esvasado, com decoração no bojo de círculos concêntricos separados por motivos verticais.

Pasta rosada, branda, micro-granulosa, com muitas pequenas calcites.

«Verniz» castanho-alaranjado, pouco aderente, de brilho acetinado. Riscos paralelos de alisamento na face interna.

Diâmetro $17,5 \mathrm{~cm}$.

83. (Est. Vili, n. ${ }^{\circ}$ 776) Tigela, de paredes curvas e aba horizontal. Pasta alaranjada, de textura folheada, com pequeníssimas areias, «Verniz» alaranjado, fino e aderente, com textura em «pele de galinha».

Diâmetro $17 \mathrm{~cm}$.

\section{Paredes finas}

O fragmento n. 71 pertence a uma taça carenada, de forma muito próxima da May et XLIII ; o assentamento do bordo leva-nos a pensar que este exemplar teria as paredes esvasadas. É datável da 2. ${ }^{\text {a }}$ metade do séc. i.

Conimbriga, 26 (1987), 77-111 
94 A. M. Diogo, J. c. Faria, M. ferreira, Fornos de Anforas de Alcácer do Sal

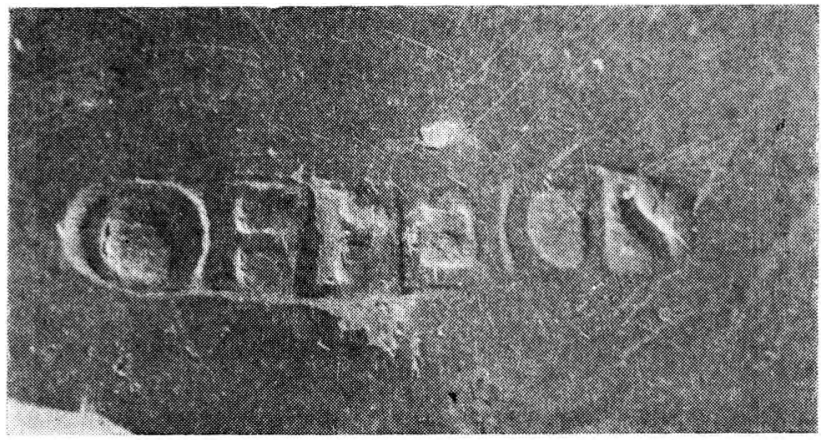

Fото 3.- Marca de FELIX

Conimbriga, 26 (1987), 77-111 
A taça 73 pertence a uma forma Mayet XXXVII, possivelmente proveniente da Bética e datável de Cláudio até fins dos Flávios. $O$ fragmento 74 pertence a uma taça de pé curto, em degrau, e paredes oblíquas, que se inclui na forma Mayet LUI. Poderá ser originária da região de Mérida e datável da segunda metade do séc. i.

$\mathrm{O}$ n. ${ }^{\circ} 75$ é o exemplar mais antigo deste conjunto de paredes finas, um bordo oblíquo de taça de forma Mayet VIII, possivelmente datável de Augusto. A 76 é um bordo oblíquo de taça, forma Mayet III, característica da 2 a $^{\mathrm{a}}$ metade do séc. I. O fundo 77 deverá pertencer a uma taça Mayet XXXVII, originária da Bética e datável de Cláudio aos fins dos Flávios.

De formas imitando sensivelmente as das sigillatas, os vasos 79 a 81 pertencem a um grupo de paredes finas pouco conhecido, que F. Mayet (1975, pág. 117) pensa poder tratar-se de «acidentes» de fabrico. Embora a sua descoberta seja ainda pouco frequente, não concordamos com a autora citada e pensamos que se trata de produtos típicos de uma oficina ainda não localizada. A datação possível é do período de Cláudio-Flávios.

71. (Est. IX, n. ${ }^{\circ}$ 784) Taça carenada de paredes ligeiramente esvasadas. Pasta fina, branda, de aspecto pulverulento, com pequeníssimos alvéolos. Cinzento claro para o interior, alaranjada para o exterior, talvez por infiltração do engobe.

Engobe em ambas as faces, laranja-acastanhado, com muitas estrias de alisamento na face interna.

Diâmetro 13,2 cm.

72. (Est. IX, n. ${ }^{\circ}$ 778) Pote, de lábio com cotovelo para a tampa. Pasta com pequenas areias, pulverulenta e branda, de aspecto folheado. Ocre-rosada, amarelada para o exterior, possivelmente por infiltração do engobe.

Superfície exterior com engobe, de tonalidade amarelada e com o bojo decorado por incisões.

Diâmetro $11,5 \mathrm{~cm}$.

73. (Est. IX, n. ${ }^{\circ}$ 781) Fundo de taça, de pé em bolacha.

Pasta fina, com pequeníssimas inclusões negras, de aspecto micro-granuloso. Tonalidade ocre-amarelada.

Vestígios de engobe alaranjado nas duas faces.

Diâmetro 3,3 cm. 
74. (Est. IX, n. ${ }^{\circ}$ 782) Fragmento de taça de paredes oblíquas e pequeno pé em degrau. Pasta fina, branda e esbranquiçada.

Engobe bege-acastanhado em ambas as faces, com uma banda rosada de cerca de 1,6 cm. na face exterior. Riscos de alisamento, no exterior e pequenas estrías paralelas no interior.

Diámetro do bordo $12,6 \mathrm{~cm}$. Diâmetro do fundo $5 \mathrm{~cm}$. Altura $5 \mathrm{~cm}$.

75. (Est. IX, n. ${ }^{\circ}$ 1622) Bordo oblíquo de taça. Pasta dura, muito fina, de tonalidade cinzenta.

Superfície externa alisada e acinzentada, superfície interna mais clara e rugosa. Espessura média 1,5 cm.

Diâmetro $10 \mathrm{~cm}$.

76. (Est. IX, n. ${ }^{\circ}$ 1625) Bordo curvo de taça. Pasta fina, com algumas pequenas areias, esbranquiçada.

Sem vestígios de engobe.

Diâmetro $8,9 \mathrm{~cm}$.

77. (Est. IX, n. ${ }^{\circ}$ 783) Fundo de taça. Paredes esvasadas, pé em degrau, com duas ranhuras concêntricas no fundo exterior. Pasta branda, pulverulenta, fina, de tonalidade ocre.

Superfície exterior rosada, com riscos provocados pelo alisamento.

78. (Ext. IX, n. ${ }^{\circ}$ 777) Fragmento de pequeno prato. Pasta muito branda, com areias atingindo os $1 \mathrm{~mm}$. Alaranjada.

Sem vestígios de engobe.

Diâmetro $14 \mathrm{~cm}$.

79. (Est. IX, n. ${ }^{\circ}$ 1621) Taça carenada. Pasta fina, friável, de textura folheada. Tonalidade ocre-alaranjada.

Conserva vestígios de engobe alaranjado.

Diâmetro $10 \mathrm{~cm}$.

80. (Est. IX, n. ${ }^{\circ}$ 756) Fragmento de pequeno prato. Pasta fina, branda, esbranquiçada com pequeno cerne alaranjado.

Vestígios de engobe bege.

Diâmetro $16 \mathrm{~cm}$.

\section{Lucerna}

O n. ${ }^{\circ} 81$ (Est. IX, n. ${ }^{\circ}$ 986) pertence a uma lucerna de volutas com o bico triangular, de tipo Loeschcke 1, Dressel-Lamboglia 9, datável dos Júlio-Cláudios.

A orla é separada do disco por três círculos concêntricos. Parece conservar vestígios de engobe bege-acastanhado, a pasta é esbranquiçada, muito fina e branda. 
Vidro

O n. ${ }^{\circ} 82$ (Est. IX, n. ${ }^{\circ} 989$ ) é o fundo de uma taça ( ?) de vidro, pé em bolacha e paredes oblíquas. Tonalidade azul-marinho, com poucas e pequenas bolhas de ar, fundo exterior riscado. Diâmetro do fundo $4,2 \mathrm{~cm}$.

Ânforas dos fornos romanos da Barrosinha I no Museu Municipal de Alcácer do Sal

Os fornos da Barrosinha I situam-se na margem direita do Sado, a cerca de $4 \mathrm{~km}$ para montante de Alcácer do Sal. São conhecidos desde finais do século passado $\left(^{8}\right)$, embora nunca tenham sido objecto de qualquer publicação monográfica. Mantém-se visível a estrutura parcialmente destruída de um forno junto ao qual e já dentro do rio, se encontra um grande amontoado de fragmentos de ânfora, de onde proveio o material aqui estudado. Estes fornos produziram ânforas de tipo Dressel $14 \mathrm{e}$ talhas.

Coordenadas hectométricas: 154.3 N e 169.3 E., na Carta Militar 1:25.000, folha n. $^{\circ} 477$.

Provenientes de recolhas efectuadas nestes fornos por Fernando Gomes e João C. Lázaro Faria, o Museu Municipal de Alcácer possui 25 fragmentos de ânfora com bordo, que dividimos em dois tipos: nove exemplares ( $36 \%$, Est. XI, n.os 3 e 4 ) de bordo esvasado e perfil subtriangular, com a aresta bem marcada; diâmetro da boca variando entre os 17,5 e os $19 \mathrm{~cm}$, média de $18,3 \mathrm{~cm}$. Os restantes $16\left(64 \%\right.$, Est. XI, n. ${ }^{\text {ss }} 1$ e 2$)$, de bordo também com o perfil subtriangular e aresta bem vincada, mas com um ressalto muito nítido, formando um lábio bem marcado e diferenciado do colo. Diâmetro da boca variando entre os 16,9 e os $19,7 \mathrm{~cm}$, sendo a média de $18,7 \mathrm{~cm}$.

Os bicos fundeiros são ocos, terminando em forma de glande pouco pronunciada e com o interior irregular, formado por uma

$\left(^{8}\right)$ Joaquim Correia B A Pтist A, Salacia, «O Archeologo Português», Vol. II, lì o 1 (1896), p. 5-10. 
língua de argila. São várias as marcas que estes fundos ostentam (Est. XI e XII, n. os 5 a 11), esgrafitadas quando as ânforas se encontravam a secar, assentes sobre a boca.

Os fragmentos n.os 12 a 14 (Est. XII), pertencem a asas de fita, bilobadas por um sulco central, como é típico das asas das Dressel 14. Têm marca de oleiro, impressa, em cartela rectangular (dimensões 4 x $1,75 \mathrm{~cm}$ ) MA.MV.S, com tria nomina separados por pontos triangulares. É uma marca já conhecida, através do exemplar que publicamos com o . $^{\circ} 12$, embora mal interpretada por Beltrán Lloris $\left({ }^{9}\right)$, que a recolheu de Leite de Vasconcelos $\left({ }^{10}\right)$.

Finalmente, referimos ainda o aparecimento de três tampas circulares com pegadeira central (Est. XI, n.os 15 e 16), duas delas perfuradas para a montagem do opérculo nas ânforas. Surgiram também vários fragmentos de talhas, de perfil não desenhável, de que há a destacar um grande fragmento de bojo, com decoração constituída por dois sulcos horizontais, largos e paralelos; e com asas em arco, de fita bilobada por um sulco central.

O fabrico e a pasta de Barrosinha I é semelhante à dos outros fornos do Sado.

\section{Fornos romanos de ânforas da Batalha. Notícia preliminar}

Há cerca de 25 anos, quando numa lavra do Sr. Mário Paulo Lança se abria uma vala para o escoamento de águas para o cultivo de arroz, surgiram três ânforas que o referido senhor recolheu.

O local onde as ânforas foram encontradas é um antigo esteiro na margem esquerda do Sado e, já que se encontravam intactas e acabadas, deve corresponder à zona do armazenamento anterior ao embarque para o local onde seriam utilizadas, possivelmente Tróia. A vala tem as coordenadas hectométricas de $159 \mathrm{~N}$.

(9) M. Beltrán Lloris, Las ánforas romanas en España, Saragoça, 1970, p. 160, fig. 53, 156.

(10) J. Leite de Vasconcelos, Excursão archeologica ao Sul de Portugal, «O Archeologo Português», Vol. IV, n. ${ }^{\circ}$ 1-6 (1898), p. 109. 
e 160.9 E., segundo a Carta Militar 1:25.000, folha ${ }^{\circ}{ }^{\circ}$ 476. Na elevação que bordeja o esteiro a Este, encontrámos vários fragmentos de ânforas, que possivelmente denunciam o local onde ficariam os fornos.

Graças à amabilidade do Sr. Paulo Lança, foi-nos possível estudar as ânforas recolhidas. Pertencem ao tipo Dressel 14, de bordo ligeiramente esvasado e secção subtriangular, a face superior com fortes vestígios de assentamento; colo cilíndrico, de superfície exterior muito ondulada; bojo cilíndrico a tender para o saco; bico fundeiro cónico terminando em glande e interior espessado por uma bola de argila.

A pasta é semelhante à dos outros fornos do Sado, micácea e com muitas inclusões ocres. A superfície é engobada, de tonalidade ocre-rosado, fino, não escondendo a textura granulosa da pasta.

Duas das ânforas recolhidas foram aplicadas à entrada do pátio da casa do Sr. Paulo Lança (Fotos 4 e 5); a terceira, que nos foi possível estudar mais em pormenor (Foto 6, Est. XIII, 2), foi guardada numa arrecadação da herdade. Tem uma marca de controle no bico fundeiro, um «B», esgrafitado quando a ânfora se encontrava a secar, assente sobre a boca (Foto 6, Est. XIII, 2B). Dimensões desta ânfora: Largura da boca variando entre 18 e $18,5 \mathrm{~cm}$. (no sentido das asas). Altura total: 102,5 cm. Altura interna: $94,5 \mathrm{~cm}$. Diâmetro máximo da pança: $31,5 \mathrm{~cm}$.

\section{Materiais da estação romana de Casas Novas no Museu Municipal de Alcácer do Sal}

A estação romana de Casas Novas, Alcácer, fica situada na margem esquerda do Sado, próxima do pequeno aglomerado populacional que lhe dá o neme e junto a um esteiro aproveitado para o cultivo do arroz, numa formação do Miocènico superior (coordenadas hectométricas : 159.2 N. e 158.8 E., segundo a Carta Militar 1:25.000, n. $\left.{ }^{\circ} 476\right)$.

No local conserva-se visível um muro, sob um pequeno canavial. Junto a este muro foi aberta uma vala para o escoamento 
100 A. M. Diogo, J. c. Faria, M. Ferreira, Fornos de Anforas de Alcácer do Sal

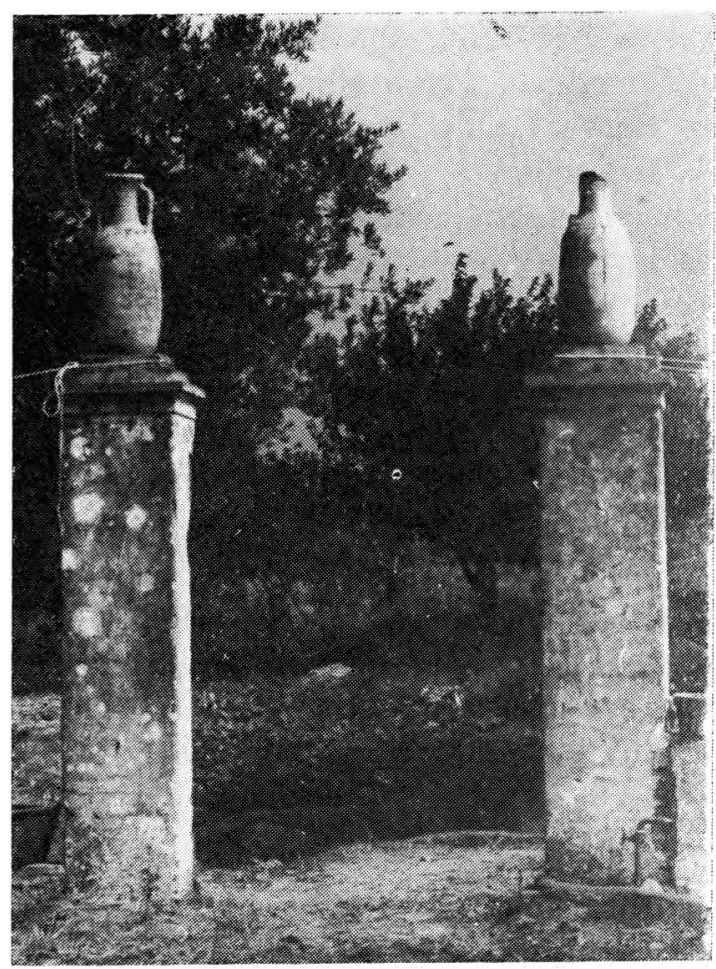

Fото 4. - Ánforas dos fornos da Batalha 
A. M. Diogo, J. c. Faria, M. ferreira, Fornos de Ânforas de Alcácer do Sal 101

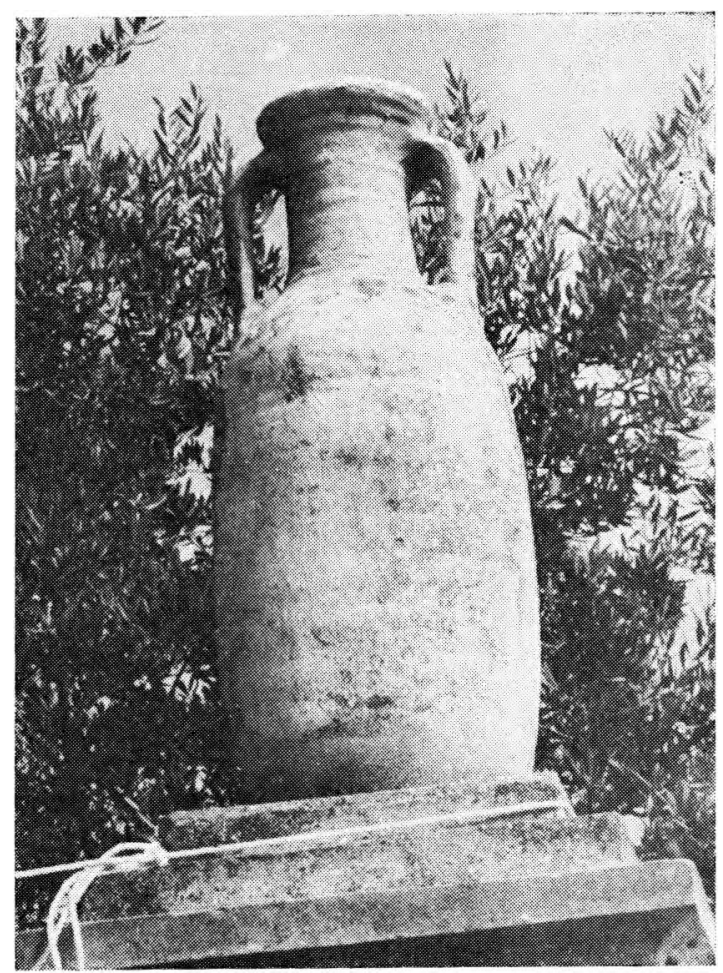

Fото 5 - Ânfora dos fornos da Batalha 
102 A. M. Diogo, J. c. Faria, M. Ferreira, Fornos de Ânforas de Alcácer do Sal

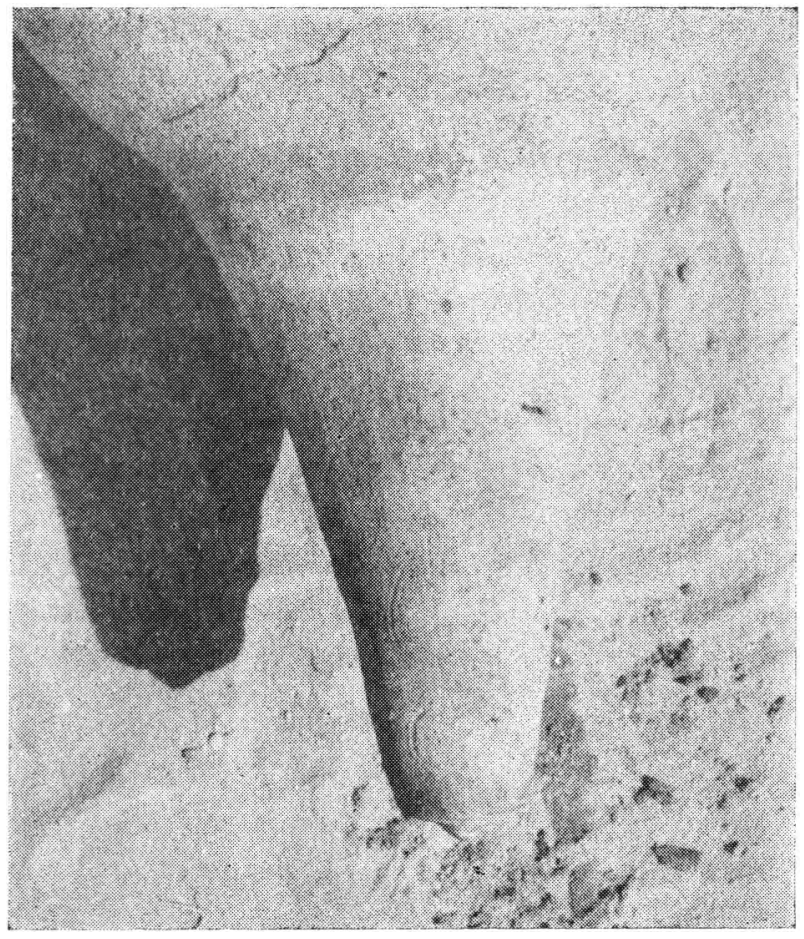

Fото 6 - Ânfora dos fornos da Batalha 
de águas, de onde é proveniente o material aqui publicado e que foi depositado no Museu Municipal de Alcácer do Sal (u).

Não nos foi ainda possível determinar o tipo de actividade desta estação e articulá-la, assim, com as restantes estações do baixo Sado. Pelo material encontrado, que é ainda pouco significativo, pela quantidade e tipo de recolha, a sua ocupação poderá situar-se cronologicamente entre os finais do séc. i e o séc. iv.

Naturalmente, a grande maioria do material é constituído por fragmentos de cerâmica comum de fabrico do Sado (12). Contentores de produtos piscícolas: os fragmentos de ânforas de tipo Dressel 14 (n.os 1-4) e Almagro 51 C (n.os 6 e 7). Cerâmica de cozinha: o pote (n. ${ }^{\circ}$ ) de bordo extrovertido, as panelas (n. ${ }^{\text {os }} 8-12$ ) de bordo introvertido e aba horizontal, dobrada sobre os ombros. Panelas de paredes simples, oblíquas (n. $\left.{ }^{\circ} 21\right)$ ou de bojo ovoide, largo e baixo (n. ${ }^{\circ} 22$ e 23 ), que tanto poderiam ter sido utilizadas para cozinhar, como para trabalhos industriais de preparação do peixe, com o bordo em aba, larga e reentrante, aptas para serem seguras pelo bordo e para serem cobertas pelas largas tampas troncocónicas (n. ${ }^{\circ} 24$ e 25), talvez também utilizadas como pratos. Formas abertas, de ir à mesa, aparecem-nos a tigela (n. $\left.{ }^{\circ} 13\right)$ de copa angulosa e bordo vertical, e os pratos covos (n. cs $^{14-20}$ ), com diversos tipos de bordo. O pequeno testo ( $\left.\mathrm{n} .{ }^{\circ} 26\right)$, cónico e de pegadeira central muito saliente, deverá pertencer a uma bilha ou a um jarro. De cerâmica de construção apenas nos apareceu o fragmento de telha ( . $^{\circ}$ 27), com o bordo em meia-cana (Est. XIV e XV).

Apenas dois fragmentos de sigillatas preservam perfis passíveis de serem desenhados: o n. ${ }^{\circ}$ 28, um prato largo de forma Hayes 27 em Clara A, com o bordo sublinhado internamente por uma ranhura

(u) Sobre as condições da descoberta da estação veja-se: A. M. Dias Diogo, Notícia da descoberta da estação romana de Casas Novas, Alcácer do Sal, «Informação Arqueológica», 8, 1987, p. 90-91.

(12) Diâmetros das bocas, em milímetros, medidos a partir das partes mais salientes dos lábios: 1-179, 2-169, 3-170, 4-(diâmetro da glande) 48, 5-160, 6-144, 7-143, 8-164, 9-169, 10-188, 11-183, 12-190, 13-170, 14-Ind., 15-205, 16-237, 17-288, 18-288, 19-266, 20-283, 21-347, 22-350, 23-374, 24-349, 25-410, 26-60, 27-(altura do bordo) 60 (altura do corpo) 24, 28-Ind., 29-228. 
e cuja datação deverá estar compreendida entre meados do séc. $\mathrm{n}$ e inicios do m. O n. ${ }^{\circ} 29$, urna forma Hayes 50, em Clara C, de fabrico muito fino, datável de 240-320/330.

$\mathrm{O}$ fragmento mais antigo que, por ora, surgiu, pertence a uma pequena taça Dragendorff 27 em T.S. Sudgálica, de bordo arredondado e saliente. Ainda significativo é um fragmento de Dragendorff $15 / 17$, de T.S. Hispânica Tardia, com o «verniz» fino, alaranjado, manchado e brilhante, correspondendo acs fabricos dos sécs. IV e V (13).

Publicamos sumariamente as peças encontradas, embora não seja esta a forma como gostaríamos de as tornar públicas. A produção de cerâmica comum nas margens do Sado é notável e merece um cuidadoso estudo tipológico e a sua integração funcional, o que evidentemente apenas será possível após a escavação dos fornos.

\section{Monte da Enchurrasqueira II. Primeira notícia}

Este local fica situado a cerca de meia distância entre os fornos da Enchurrasqueira e do Vale da Cepa (coordenadas hectométricas 161.1 N., 152.6 E., na Carta Militar 1:25.000, folha n. ${ }^{\circ}$ 467). A superfície encontra-se juncada de pequenos fragmentos de ânforas, e poderá eventualmente corresponder a entulheiras de fornos.

O facto de não se terem aqui recentemente aberto valas para o escoamento de águas impediu que se pudessem recolher elementos mais significativos.

A generalidade dos fragmentos encontrados (Estampa XVI) pertence a ânforas do tipo Dressel 14/Beltrán IVb, na sua vanante de lábio arredondado, muito espessado (o exemplar n. ${ }^{\circ} 2$ encontra-se rolado). Os bicos fundeiros integram-se na variante em glande e com a superfície interna em forma de bola.

As pastas, características dos fornos do Sado, são geralmente alaranjadas (o $\mathrm{n} .^{\circ} 3$ tem uma tonalidade ocre), muito micáceas,

(13) Françoise May Eт, Fouilles de Conimbriga, IV, p. 155. 
arenosas de pequeno grão e com muitos nódulos ocres, abundantes fendas e alvéolos. As superfícies são da tonalidade da pasta, rugosas, alisadas a trapo ou a pincel.

$\mathrm{O}$ n. ${ }^{\circ} 4$ é um fragmento de bordo de pote.

A corresponder a fornos, não haveria evidência de o fabrico neste local ter sobrevivido ao fim da produção das Dressel 14.

\section{Material da Comenda no Museu do Mar, Cascais}

A Comenda fica situada na margem direita do Sado, a cerca de 4,5 km para jusante da cidade de Setúbal, na margem esquerda da desembocadura da Ribeira de Aravil. A estação é conhecida desde finais do século passado $\left({ }^{14}\right)$, e trata-se de um centro de transformação de pescado. Reconhecem-se, ainda hoje, restos de cetárias e é possível que uma construção de lateres que mostra um arco de volta inteira, tida por alguns autores como pertencente a um conjunto termal $\left({ }^{15}\right)$, pertença, na realidade, à fornalha de um forno de cozer cerâmica, para cuja existência apontam vários fragmentos de vasos queimados aquando da cozedura (n. os $8,10,11,14,15$ e 17 do nosso catálogo) e as muitas pedras circulares, de granito, actualmente utilizadas como âncoras pelos pescadores, e que poderão ter pertencido a rodas de oleiro.

Publicamos o catálogo das peças da Comenda que o Museu do Mar possuía. Trata-se, fundamentalmente, de uma colecção de potes e vasos largos e pouco profundos, para o transporte e transformação do pescado.

A peça datável mais antiga que se encontrou na Comenda é um fragmento de sigillata itálica, com a marca do oleiro aretino CNAEVS ATEIVS ${ }^{(16)}$. O fragmento deverá pertencer a uma taça Goudineau 27, do período clássico da sigillata aretina. Os vasos de sigillata clara $\mathrm{D}\left(\mathrm{n} .{ }^{\mathrm{os}} 21\right.$ e 22$)$, são as peças mais recentes, datáveis do séc. v. Os fragmentos n. ${ }^{\text {os }} 3$ e 4 pertencem a ânforas de tipo Almagro 51A-B.

(14) Yeja-se Joaquim Rasteiro, 1897.

(15) Entre outros, Yitor Gonçalves, 1964, p. 5.

(16) Id., ibid., fig. 9, I e II. 


\section{CATÁLOGO}

1. (Est. XVII, n. ${ }^{\circ}$ 1494) Ânfora de tipo Dressei 14. Fabrico do Sado. Bordo perolado.

Pasta alaranjada, com pequenas areias, alterada pelas águas do rio. Recolhido do fundo do estuário do Sado, na confluência com a ribeira de Aravil.

Diâmetro da boca: $16,8 \mathrm{~cm}$.

2. (Est. XVII, n. ${ }^{\circ}$ 2906) Ânfora de tipo Dressel 14. Fabrico do Sado. Bordo triangular com a face superior convexa.

Pasta alaranjada, de pequenas areias, sem micas visíveis, aspecto folheado, com pequenas fendas. Superfícies alaranjadas, mais claras do que a pasta.

Os vestígios de cal que apresenta nas superfícies sugerem-nos que o fragmento tenha sido reutilizado como material de construção. Diâmetro da boca: $17 \mathrm{~cm}$.

3. (Est. XVII, n. ${ }^{\circ}$ 2980) Ânfora. Fabrico do Sado. Lábio alto, almendrado e esvasado.

Pasta relativamente fina, muito micácea, de pequeníssimas micas, branda, de aspecto folheado, com alvéolos.

Diâmetro impossível de determinar.

4. (Est. XVII, n. ${ }^{\circ}$ 2880) Ânfora. Fabrico do Sado. Lábio alto, ligeiramente almendrado e esvasado.

Pasta alaranjada, branda, muito micácea, com pequenas fendas e alvéolos ferruginosos.

Diâmetro da boca: $12 \mathrm{~cm}$.

5. (Est. XVII, n. ${ }^{\circ}$ 2905) Ânfora de tipo Almagro 51 C. Fabrico do Sado. Lábio triangular.

Pasta laranja-amarelada, com pequenas areias e pequeníssimas micas. Superfícies muito micáceas e alteradas pela água.

Diâmetro da boca: $12 \mathrm{~cm}$.

6. (Est. XVII, n. ${ }^{\circ}$ 2884) Ânfora de tipo Almagro 51 G. Fabrico do Sado. Boca esvasada de lábio triangular. Asa de fita, trilobada, nascendo da sobeira do bordo.

Pasta alaranjada, fina e dura, com pequeníssimas micas, raras areias atingindo os $2 \mathrm{~mm}$.

Diâmetro da boca: 11,8 .

7. (Est. XVII, n. ${ }^{\circ}$ 2889) Tampa de ânfora. Fabrico do Sado. Circular com pegadeira central.

Pasta alaranjada, arenosa de pequenas areias. Superfícies mais rosadas, alisadas e rugosas. 
8. (Est. XYII, n. ${ }^{\circ}$ 2913) Tegula. Fabrico do Sado. Bordo em meia-cana Superfícies beges, mais escura na base. Largo cerne avermelhado. Queimada e distorcida pela cozedura.

Altura do bordo: $5,2 \mathrm{~cm}$. Altura do corpo: $1,8 \mathrm{~cm}$.

9. (Est. XVIII, n. ${ }^{\circ}$ 2917) Garrafa. Possivelmente fabrico do Sado. Colo alto e apertado, com um cotovelo de onde nasce uma asa de fita. Corpo prismático, de paredes oblíquas e arqueadas.

Pasta alterada pela água, bicolor, ocre-alaranjada, cinzento-esverdeada para o interior. Branda, com pequenas areias, micácea, nódulos ferruginosos. Superfície exterior rolada, interior de tonalidade alaranjada.

Diâmetro máximo do bojo: $21,7 \mathrm{~cm}$.

10. (Est. XVII, n. ${ }^{\circ}$ 2878) Pote. Fabrico do Sado. Bordo ligeiramente revirado para fora, ombros convergentes e quase rectos.

Pasta arenosa, queimada do forno.

Diâmetro da boca: $16,4 \mathrm{~cm}$.

11. (Est. XVII, n. ${ }^{\circ}$ 2881) Pote. Fabrico do Sado. Bordo revirado para fora e arqueado, ombros arredondados.

Pasta arenosa, queimada da cozedura.

Diâmetro da boca: $14,9 \mathrm{~cm}$.

12. (Est. XVII, n. ${ }^{\circ}$ 2903) Pote. Fabrico do Sado. Bordo revirado para fora e arqueado, ombros quase rectos.

Pasta ocre-acinzentada, branda, muito micácea, relativamente depurada, com pequenas areias e fendas. Superfícies muito micáceas, alteradas pela água.

Diâmetro da boca: $14,9 \mathrm{~cm}$.

13. (Est. XVIII, n. ${ }^{\circ}$ 2877) Pequena talha. Fabrico do Sado. Bordo em forma de rim, dobrado sobre os ombros.

Pasta de tonalidade alaranjada, dura, relativamente fina, micácea, de aspecto folheado, com pequenos alvéolos e fendas atingindo os $4 \mathrm{~mm}$, abundantes nódulos ferruginosos. Superfícies bege-rosadas, alisadas.

Diâmetro da boca: $22 \mathrm{~cm}$.

14. (Est. XVIII, n. ${ }^{\circ}$ 2910) Taça. Fabrico do Sado. Bordo amendoado, copa em dois lanços, com cotovelo bem marcado.

Pasta queimada da cozedura.

Diâmetro da boca: $29,1 \mathrm{~cm}$.

15. (Est. XVIII, n. ${ }^{\circ}$ 2888) Tacho? Fabrico do Sado. Bordo em aba mais sobressaliente para o interior, corpo cilíndrico.

Pasta queimada da cozedura.

Diâmetro da boca: $27,5 \mathrm{~cm}$. 
16. (Est. XVIII, n. ${ }^{\circ}$ 2876) Almofariz ou alguidar. Fabrico do Sado. Bordo amendoado, sobressaliente para ambos os lados. Copa arqueada.

Pasta alaranjada, com pequeno cerne acinzentado, aspecto folheado com fendas e alvéolos, micácea, com pequenas areias e nódulos ferruginosos. Superfícies beges, alisadas mas rugosas.

Diâmetro da boca: $41,8 \mathrm{~cm}$.

17. (Est. XVIII, n. ${ }^{\circ}$ 2875) Almofariz ou alguidar. Fabrico do Sado. Bordo amendoado, largo, sobressaliente para ambos os lados, copa arqueada.

Pasta castanho-acinzentada, dura, arenosa, muito micácea. Superfícies beges, com manchas acinzentadas do contacto com o fogo. Diâmetro da boca: $31 \mathrm{~cm}$.

18. (Est. XVIII, n. ${ }^{\circ}$ 2914) Taça? Fabrico do Sado. Bordo arqueado dentro, paredes esvasadas.

Pasta laranja-amarelada, dura, de aspecto folheado, com pequenas areias e minúsculas micas. Superfície interna alaranjada, da tonalidade da pasta. Superfície externa com engobe ocre-alaranjado e bandas largas de alisamento.

19. (Est. XVIII, n. ${ }^{\circ}$ 2887) Alguidar? Fabrico do Sado. Bordo triangular, engrossado para o interior, corpo troncocònico a tender para o cilíndrico.

Pasta alaranjada, dura e relativamente fina, muito micácea, com fendas e alvéolos. Superfície externa com engobe acinzentado. Diâmetro da boca: $39 \mathrm{~cm}$.

20. (Est. XIX, n. ${ }^{\circ}$ 2915) Almofariz. Terra sigillata clara D. Forma Lamboglia 38, Hayes 91.

Pasta alaranjada, com muitas calci tes, branda. «Verniz» alaranjado na superfície interna e sobre o gancho externo. Superfície externa sem «verniz», com bandas de alisamento e ranhuras provocadas pelo arrastamento dos elementos não-plásticos.

Diâmetro da boca: $25,6 \mathrm{~cm}$.

21. (Est. XIX, n. ${ }^{\circ}$ 2901) Tigela. Terra sigillata clara D. Forma Lamboglia 57, Hayes 73.

Pasta rosada, branda, de aspecto folheado, com pequenas fendas e pequenas calcites. «Verniz» afectado pela água, existente sobre a superfície interna, fino, rosado. Superfície exterior alisada, com pequenos sulcos provocados pelo arrastamento das areias.

Diâmetro da boca: $17 \mathrm{~cm}$. 
22. (Est. XIX, n. ${ }^{\circ}$ 2915) Idem.

Pasta alaranjada, dura, com pequenas calcites e fendas. «Verniz» alterado pela água e apenas cobrindo a superfície interna, alaranjado, muito fino e sem brilho. Riscos de arrastamento das areias na superfície exterior.

Diâmetro da boca: $18,1 \mathrm{~cm}$.

Fornos da Morgada. Primeira notícia

Os fornos da Morgada encontram-se entre os que descobrimos graças à análise das cartas geológicas e das fotografias aéreas. Ficam situados na margem esquerda do Sado a cerca de $1 \mathrm{~km}$ para Oeste da ponte de caminho de ferro. Utilizariam as argilas dos terraços plistocénicos que lhes estão próximos (155.4 N., 165.2 E., segundo a Carta Militar 1:25.000, n. ${ }^{\circ} 476$ ).

Para além de pequenos fragmentos de potes, no que respeita a ânforas, apenas foram encontrados vestígios de fabrico de Dressel 14 (Est. XX), com os lábios espessados, extrovertidos e vestígios de assentamento. Bicos fundeiros troncocónicos, de glande pronunciada e superfície interna em bola. Dois apresentam marcas de controlo, um «B» esgrafitado quando a ânfora se encontrava invertida. O fabrico é típico do Sado, de pasta clara, arenosa e micácea.

$\mathrm{O}$ fragmento $\mathrm{n}^{\circ} 9$ pertence a um prato covo, revestido com um engobe vermelho-pompeiano. $\mathrm{O}$ tipo de pasta aparenta uma origem local.

\section{CATÁlOGO}

1. (Est. XX) Fragmento de boca, colo e asa de Dressel 14. Lábio extrovertido, espessado e saliente, a tender para o quadrangular. Diâmetro do lábio: $175 \mathrm{~mm}$.

2. (Est. XX) Fragmento de boca e colo de Dressel 14. Lábio extrovertido, triangular/convexo, de aresta viva.

Diâmetro do lábio: $177 \mathrm{~mm}$.

3. (Ext. XX) Fragmento de boca e colo de Dressel 14. Lábio extrovertido, espessado, triangular/convexo e saliente.

Diâmetro do lábio: $190 \mathrm{~mm}$. 
4. (Est. XX) Fragmento de boca e colo de Dressel 14. Lábio extrovertido, espessado e saliente, a tender para o quadrangular. Diâmetro do lábio: $180 \mathrm{~mm}$.

5. (Est. XX) Fragmento de boca e colo de Dressel 14. Lábio ligeiramente extrovertido, espessado, triangular/convexo, de sobeira moldurada.

6. (Est. XX) Fragmento de bico fundeiro de Dressel 14. Troncocònico, terminando em glande e interior em bola.

Tem um «B» invertido, esgrafitado na superfície externa $(77 \mathrm{X}$ X $24 \mathrm{~mm}$.).

Diâmetro da glande: $43 \mathrm{~mm}$.

7. (Est. XX) Fragmento de bico fundeiro de Dressel 14. Troncocònico, terminando em glande e interior em bola.

Conserva vestígios de um «B» invertido, esgrafitado na superfície externa.

Diâmetro da glande: $40 \mathrm{~mm}$.

8. (Est. XX) Fragmento de bico fundeiro de Dressel 14. Troncocònico, terminando em glande e interior em bola.

Diâmetro da glande: $41 \mathrm{~mm}$.

9. (Est. XX) Fragmento de bordo e copa de prato covo. Bordo vertical, espessado, a tender para o biselado.

Pasta castanho-alaranjada, de aspecto folheado, branda e arenosa, com pequenos nódulos ocres, partículas negras, grãos de cal e abundantes quartzos leitosos e micas. Superfícies mostrando bandas de alisamento e cobertas com um engobe vermelho-pompeiano, aplicado por imersão.

Diâmetro do bordo: $235 \mathrm{~mm}$.

\section{BIBLIOGRAFIA}

Alarcão, Jorge de, 1974, Cerâmica comum local e regional de Conímbriga, Coimbra.

Alarcão, Jorge de, Manuela Delgado, Françoise Mayet, Adília Moutinho de Alarcão, Salete da Ponte, 1976, Fouilles de Conimbriga. VI - Céramiques diverses et verres, Paris.

Almeida, F. de, G. Zbyzewsin, O. da Veiga Ferreira, 1971, Descoberta de fornos lusitano-romanos na região da Mar ateca [Setúbal), «O Arqueólogo Português», Sér. Ill, Vol. V, Lisboa, p. 155-165.

Baptista, Joaquim Correia, 1896, Salada, «O Archeologo Português», Vol. Il, n. ${ }^{\circ}$, Lisboa, p. 5-10.

Conimbriga, 26 (1987), 77-111 
Beltrán Lloris, M., 1970, Las ánforas romanas en España, Saragoça.

Cardoso, G., 1978, Anforas romanas no Museu do Mar (Cascais), «Conimbriga», XVII, Coimbra, p. 63-78.

Coelho-Sonres, A. e C. Tavares da Silva, 1978, Anforas romanas da área urbana de Setúbal, «Setúbal Arqueológica», IV, Setúbal, p. 171-201.

— 1979, Anforas romanas da Quinta da Alegria (Setúbal), «Setúbal Arqueo lógica», V, Setúbal, p. 205-221.

Cost A, A. I. Marques da, 1905, Estações prehistóricas dos arredores de Setúbal, «O Archeologo Português», Vol. X, n. ${ }^{\circ} 6$ a 9, Lisboa, p. 185-193.

Delgado, M., F. Mayet e A. Moutinho de Alarcão, 1975, Fouilles de Conimbriga. IV - Les sigillées, Paris.

Diogo, A. M. Dias, 1980, Fornos de anforas do Monte do Bugio. Notícia preliminar, «Conimbriga», XX, Coimbra, p. 147-150.

---- 1983, Fornos de ânforas do Monte da Enchurrasqueira e do Vale da Cepa. Notícia preliminar, «Conimbriga», XXII, Coimbra, p. 209-215.

Diogo, A. M. T)i\&s, et alii, 1984, O material dos fornos romanos da Enchurrasqueira no Museu do Mar, Cascais, (Série Arqueológica, I, Sep. 3), Cascais.

----- 1985, O material dos fornos romanos do Abúl no Museu do Mar, Cascais, (Série Arqueológica, I, Sep. 4), Cascais.

Faria, João Carlos L., Marisol A. Ferreira, 1986, Estações inéditas da época romana do concelho de Alcácer do Sal. Breve notícia, "Conimbriga», XXV, Coimbra, 41-51.

Ferreira, O. da Veiga, 1966-67, Algumas considerações sobre as fábricas de conservas de peixe da Antiguidade encontradas em Portugal, "Arquivo de Beja», XXIII-XXIV, Beja, p. 123-134.

Gonçalves, Vítor dos Santos, 1964, Notas sobre algumas povoações dos arredores de Setúbal. I - A estação romana da Comenda e o problema da desaparição de Cetóbriga, «Boletim da Sociedade de Espeleología Portuguesa», Vol. II, n. ${ }^{\circ}$ 1, Lisboa, p. 1-14.

KeAY, S. J., 1984, Late Boman Amphorae in the Western Mediterranean. A typology and economic study: the Catalan evidence, Oxford.

Mayet, Françoise, 1975, Les céramiques à parois fines dans la Péninsule Ibérique, Paris.

Nolen, J., 1976-77, Alguns fragmentos de «paredes finas» de Miróbriga, «Setúbal Arqueológica», II-III, Setúbal, p. 423-452.

PARKer, A. J., 1977, Lusitanian amphoras, in Méthodes classiques et méthodes formelles dans l'étude des amphores, Roma, p. 35-46.

Rasteiro, Joaquim, 1897, Notícias arqueológicas da Península da Arrábida, «O Archeologo Português», III, n. ${ }^{\circ} 1$ e 2, Lisboa, p. 4 e 5.

Silva, Carlos Tavares de, et alii, 1890-81, Escavações arqueológicas no castelo de Alcácer do Sal (campanha de 1979), «Setúbal Arqueológica», VI-VII, Setúbal, p. 149-218.

Vasconcelos, J. Leite de, 1898, Excursão archeologica ao Sul de Portugal, «O Archeologo Português», IV, n. ${ }^{\circ}$ 1-6, Lisboa, p. 103-134.

Conimbriga, 26 (1987), 77-111 
EST. I
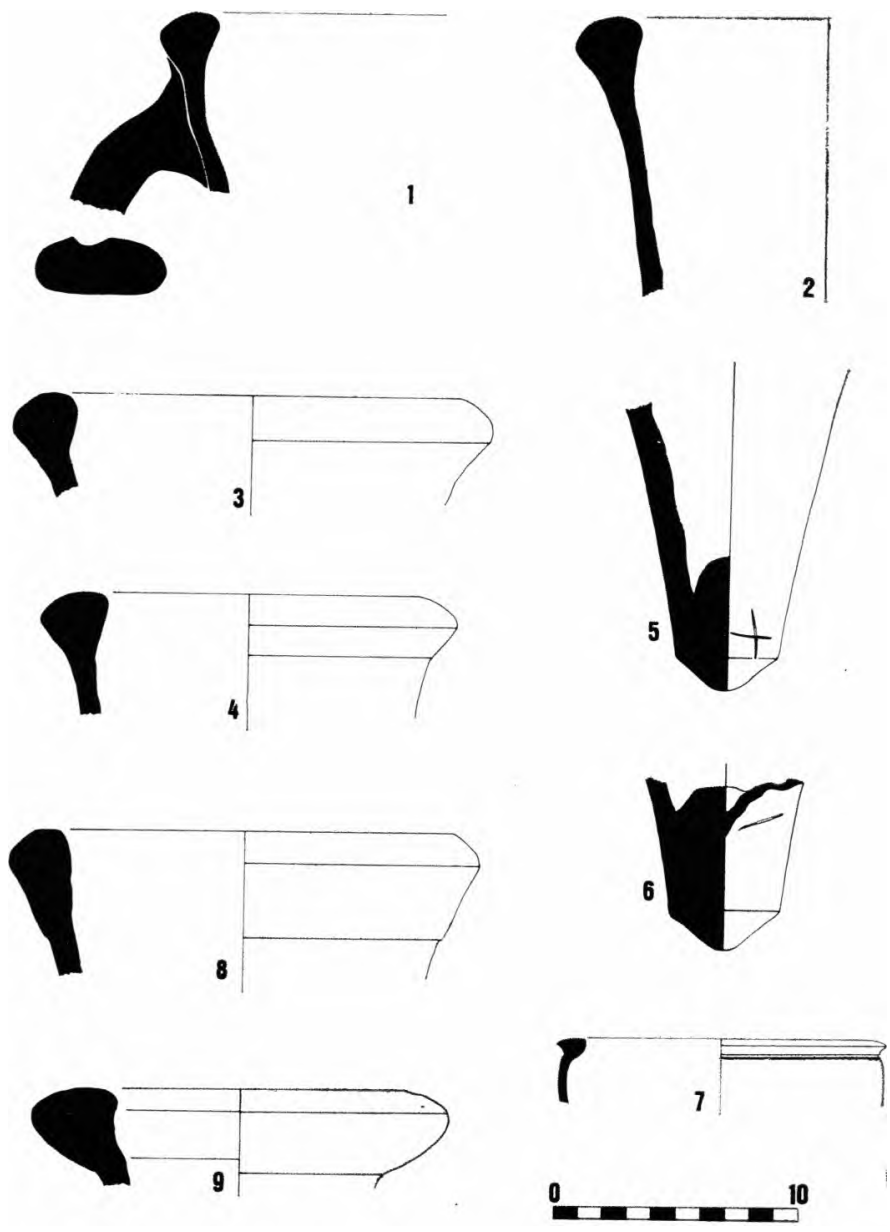
EST. 11
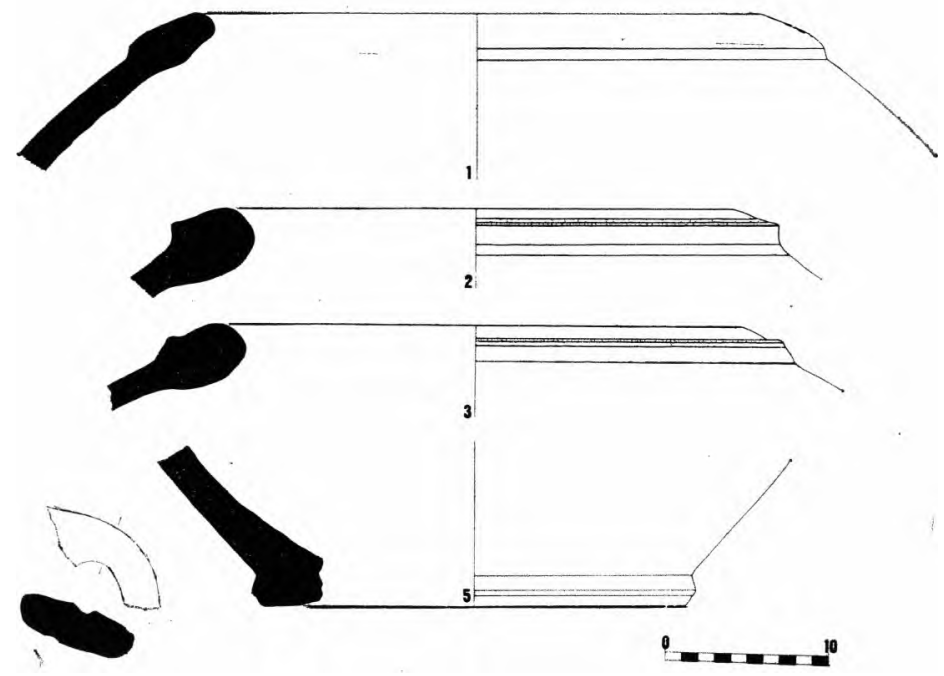


$$
\begin{array}{ll}
1 & 11 \\
1 & 1
\end{array}
$$



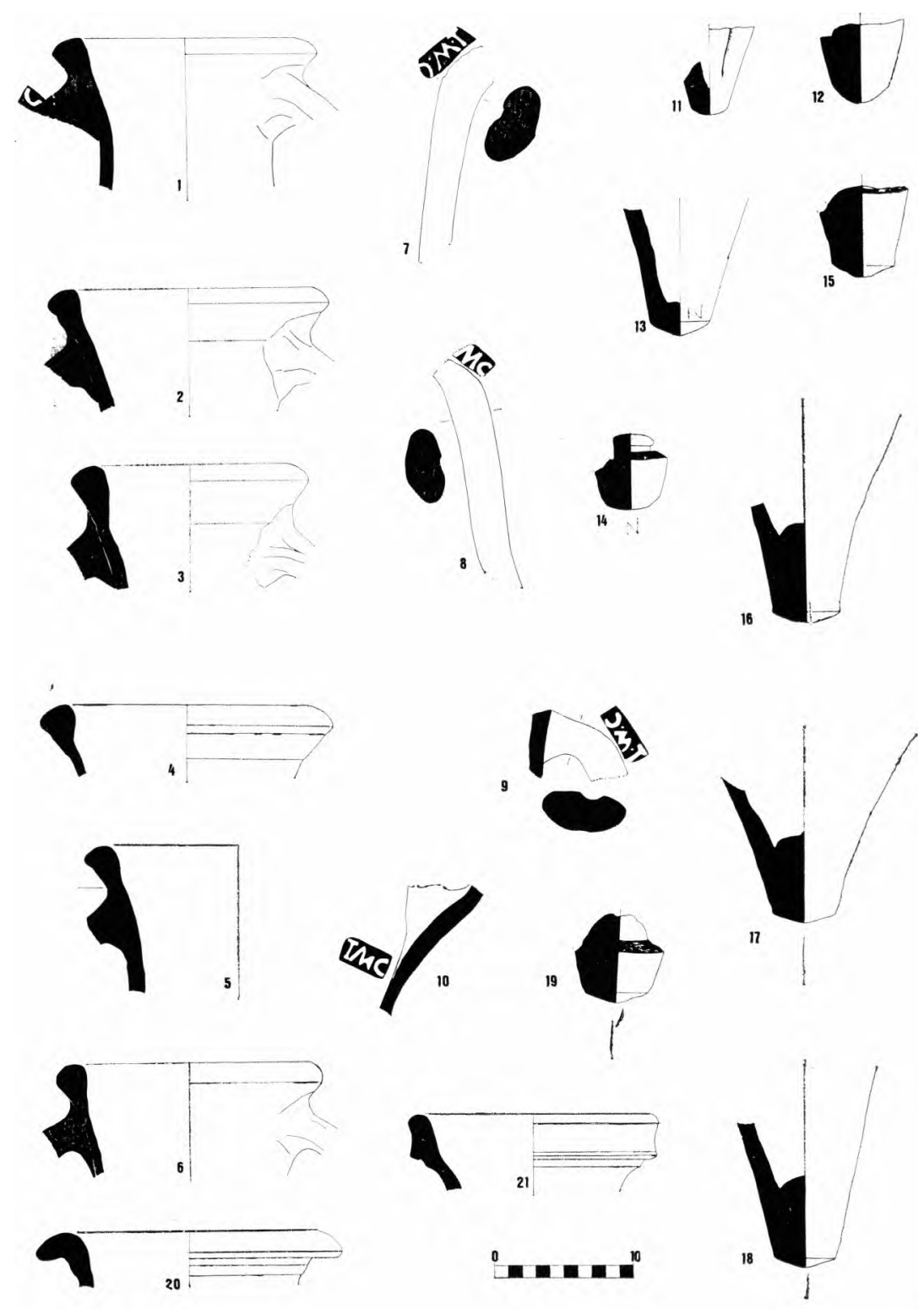

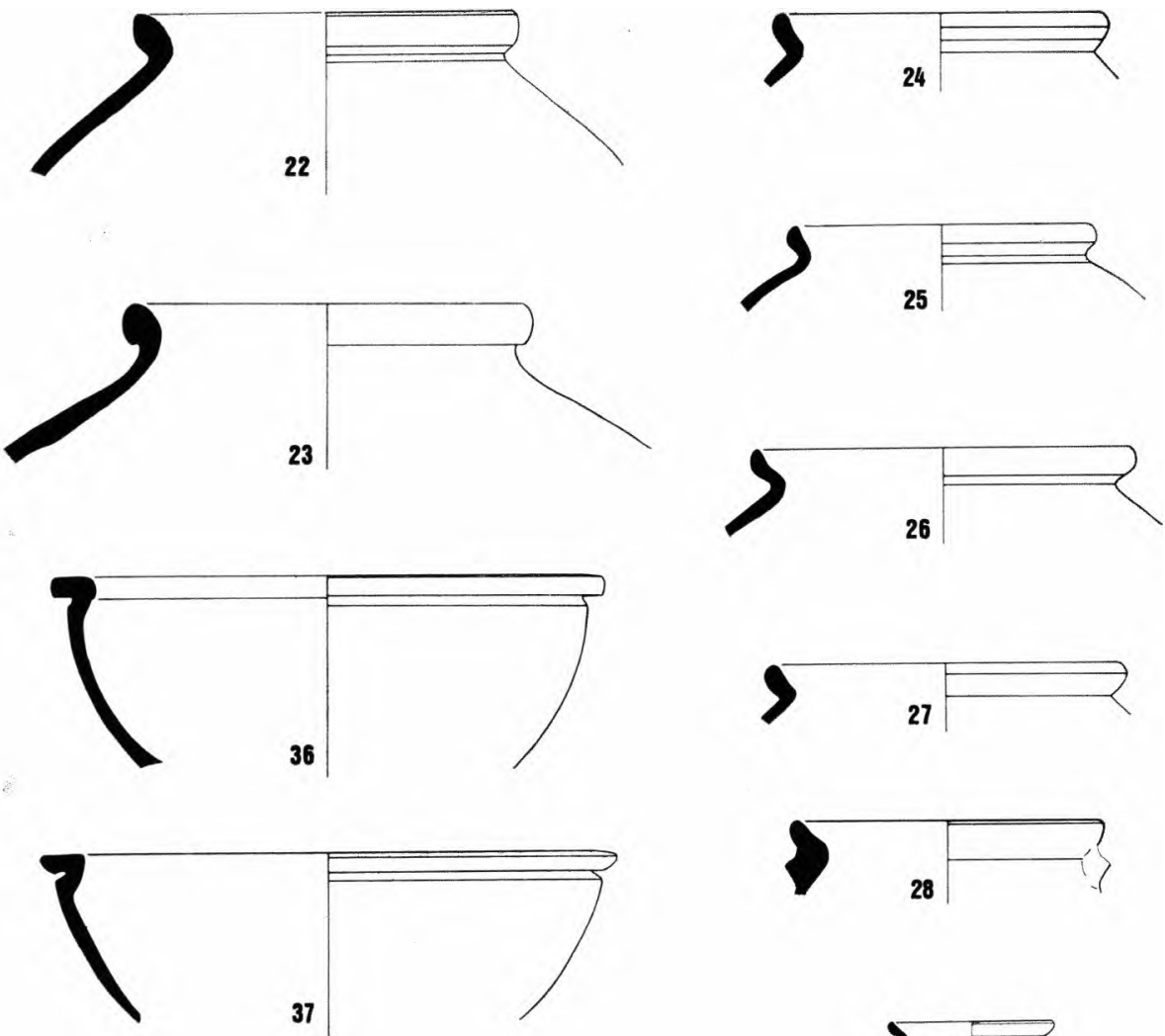

34
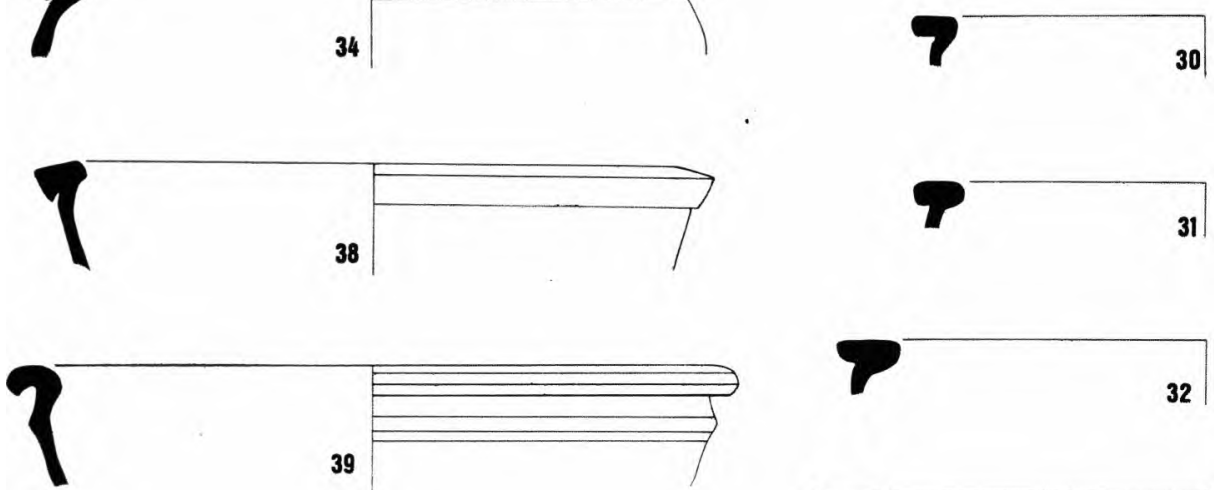

39

0 口ص⿴囗十

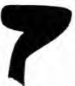


Est. VI
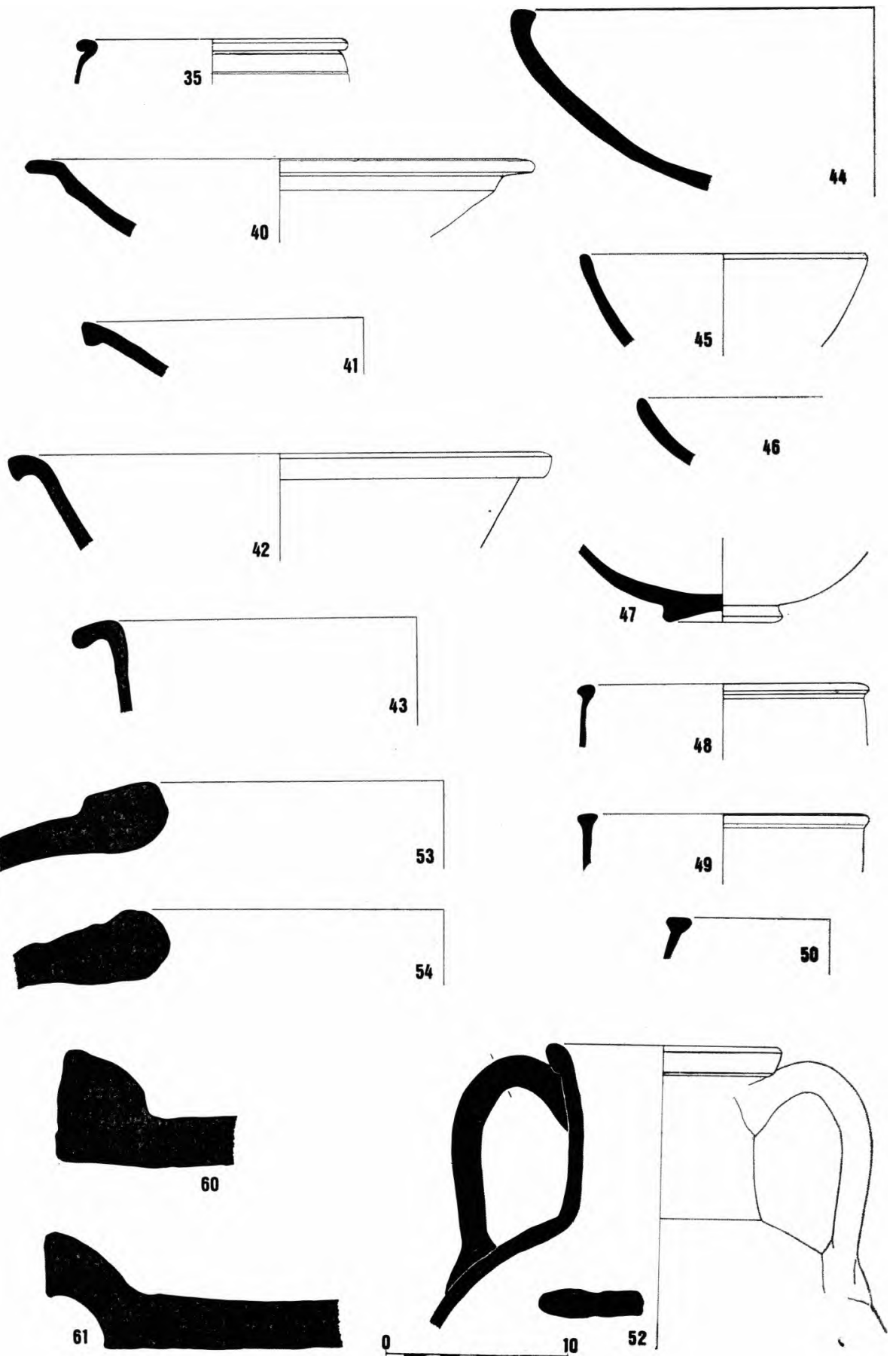

EST. Vili
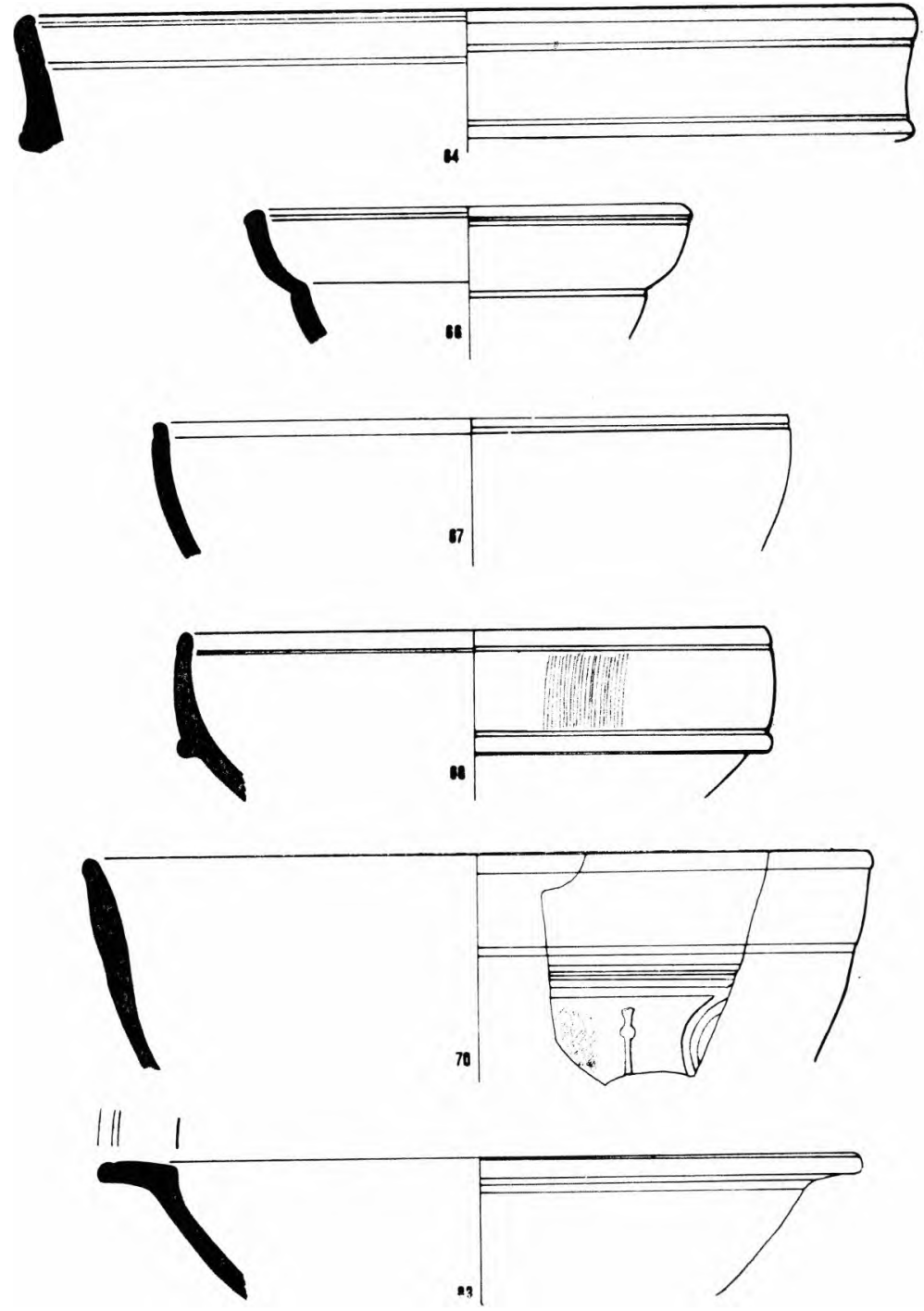

0
$\square \quad 1 \quad 15$ 
Est. IX
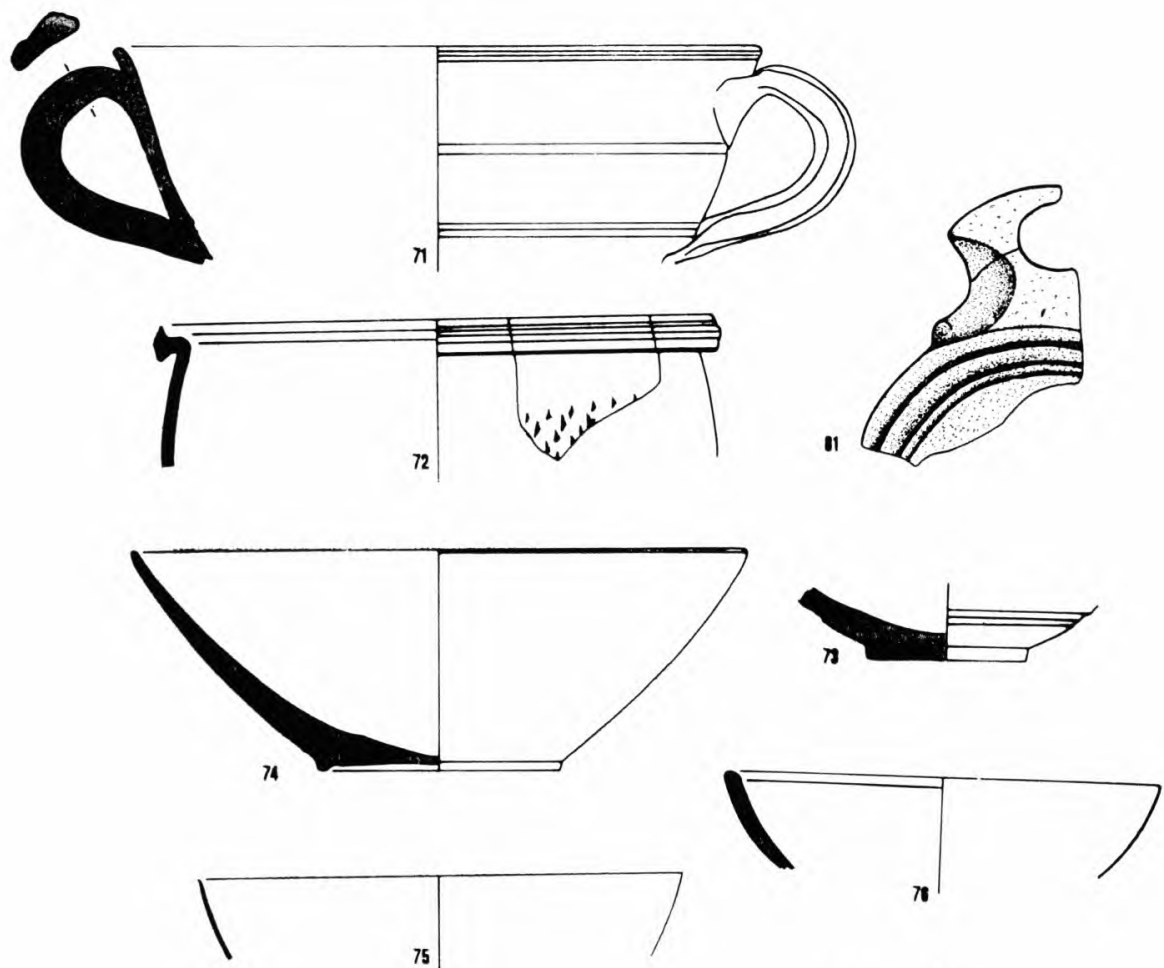

75
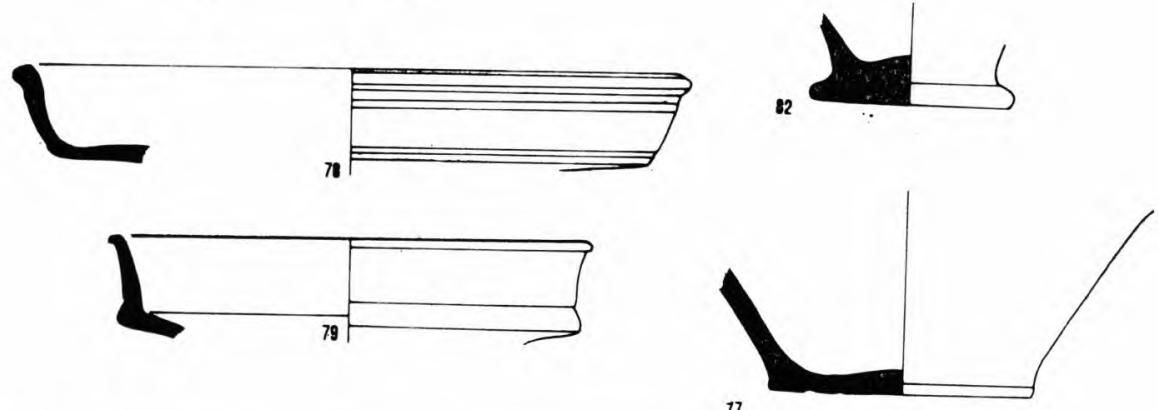

1
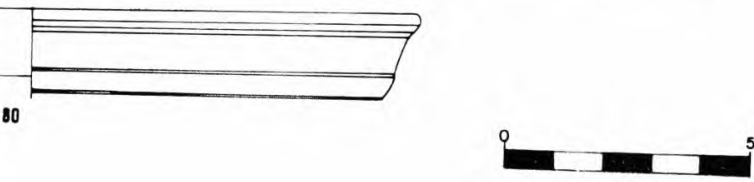
EsT. X
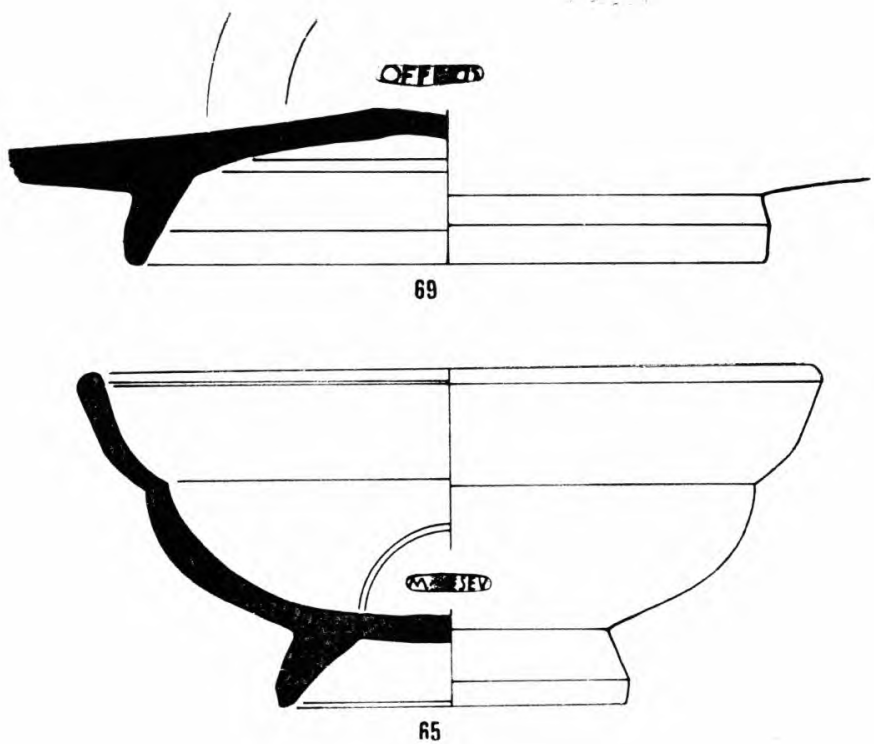

Dis

7

"IAMC

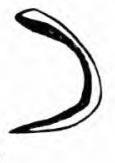

62

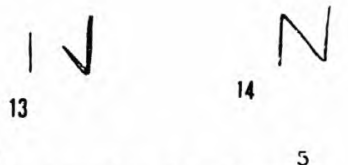

$121^{\prime}$

$=$ 


$$
\int_{-2}^{1}=1
$$


Est. XII

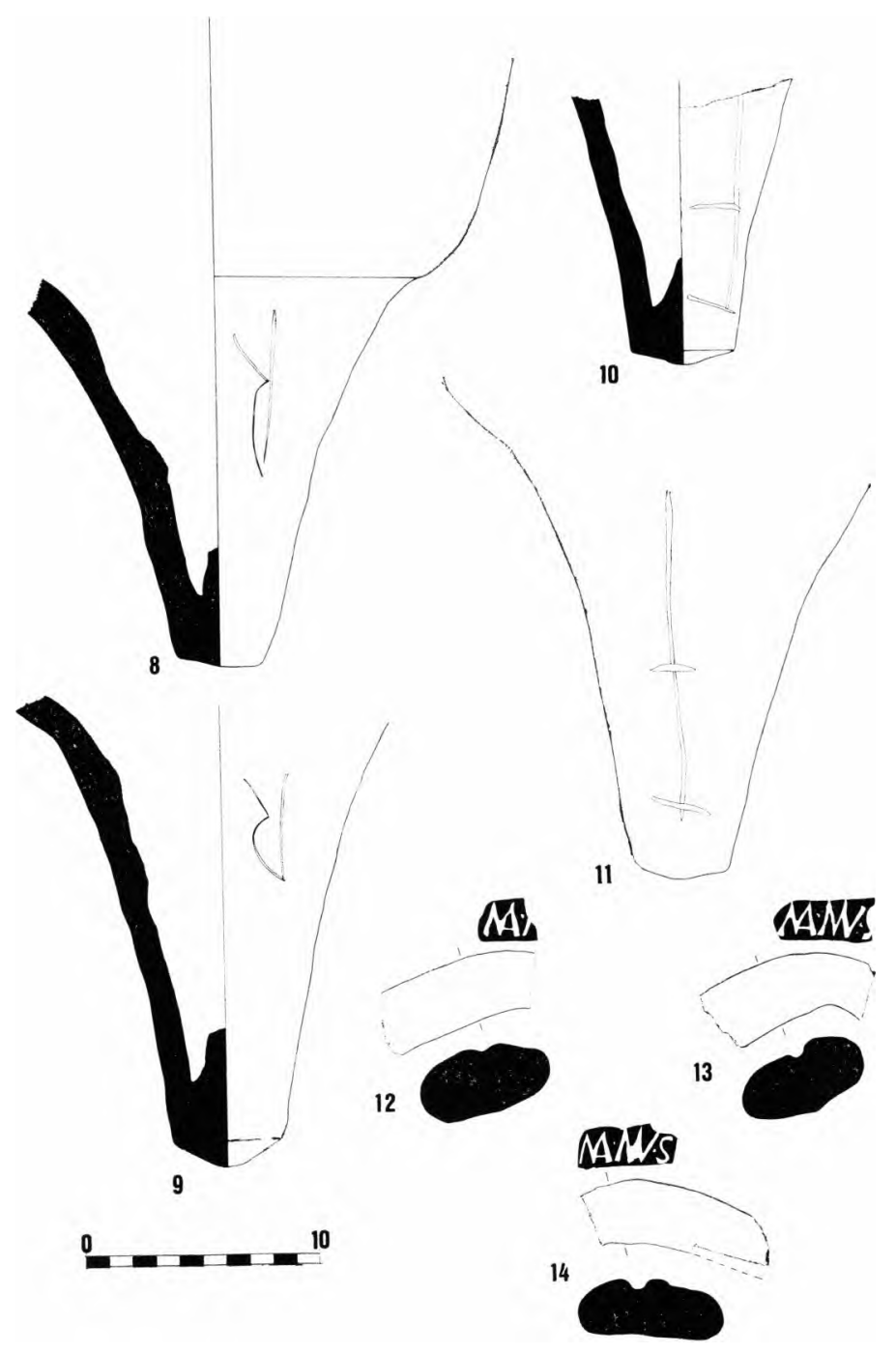


Est. XIII

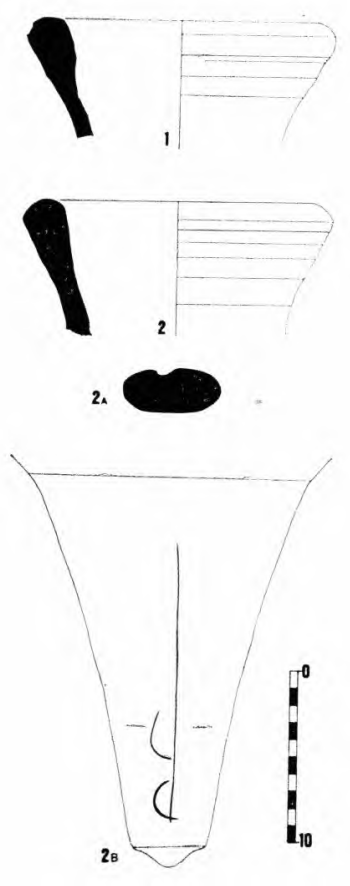


est. XIV
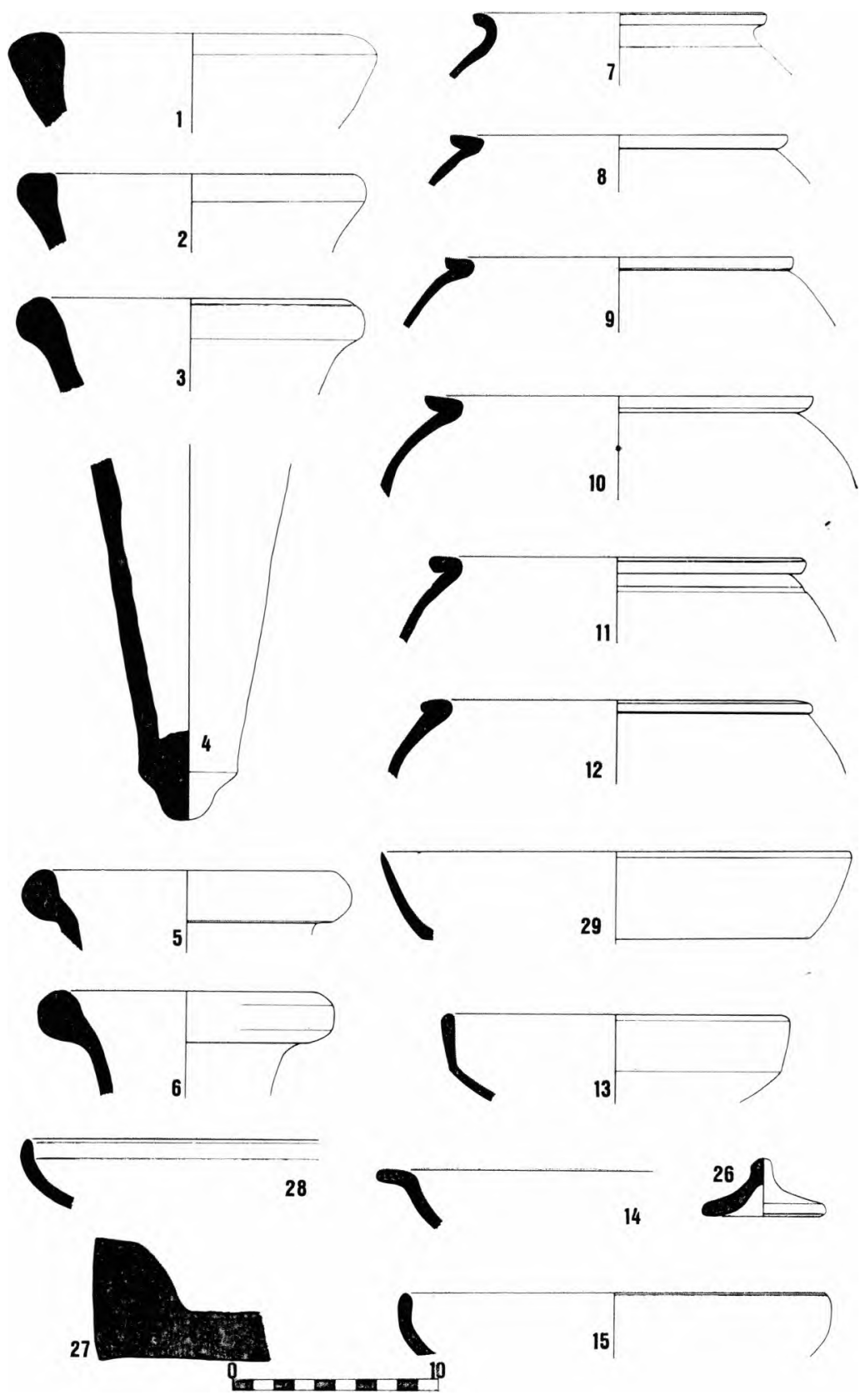

15 
EST. XV
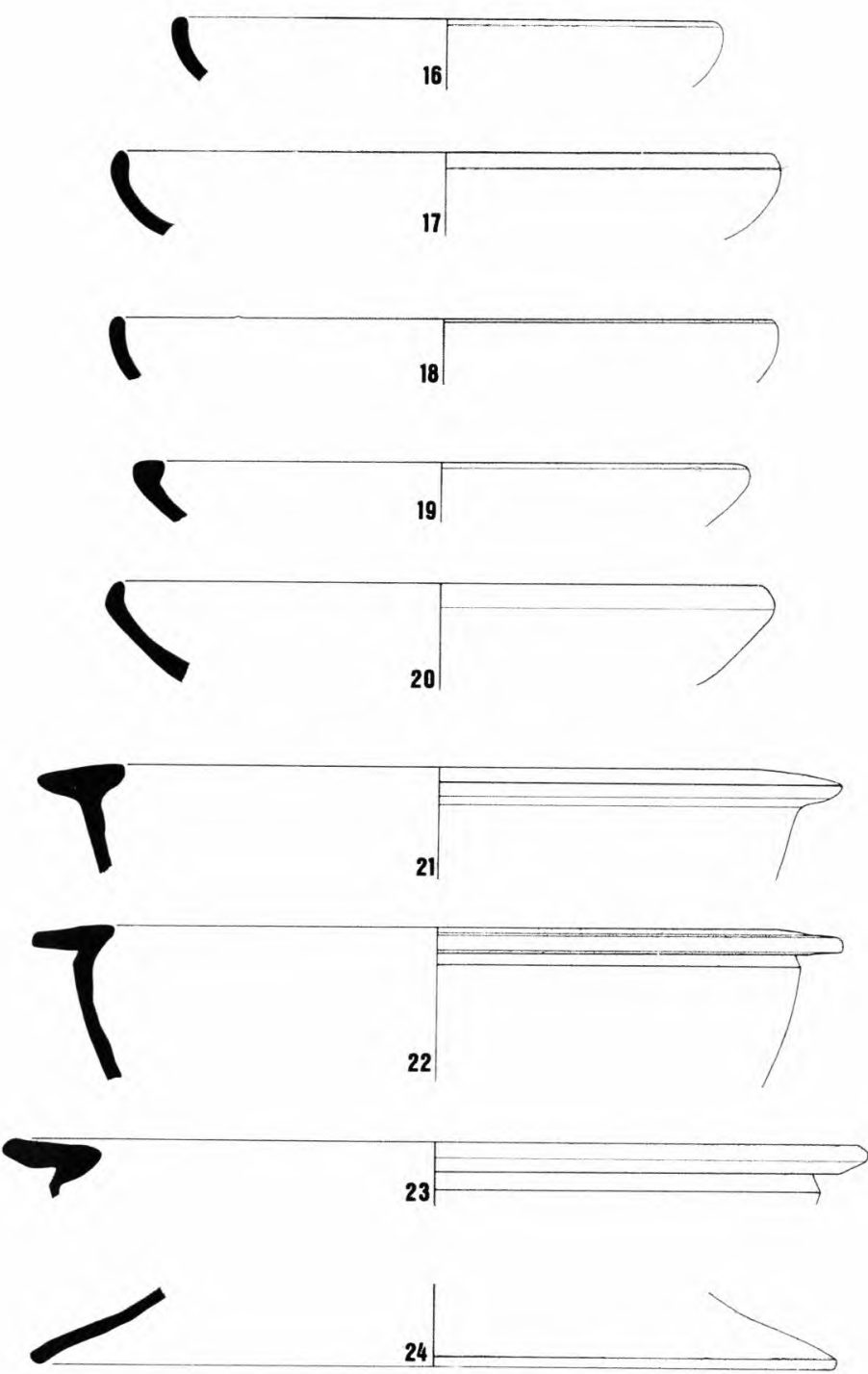

$0=-10$

25

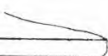


est. XVI

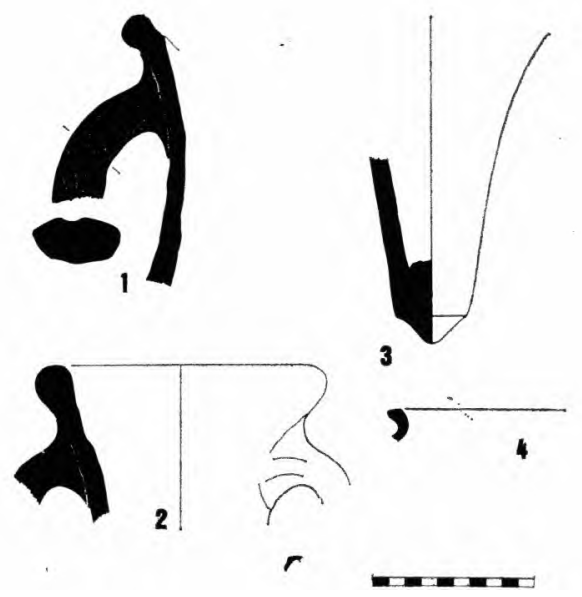


est. XVII

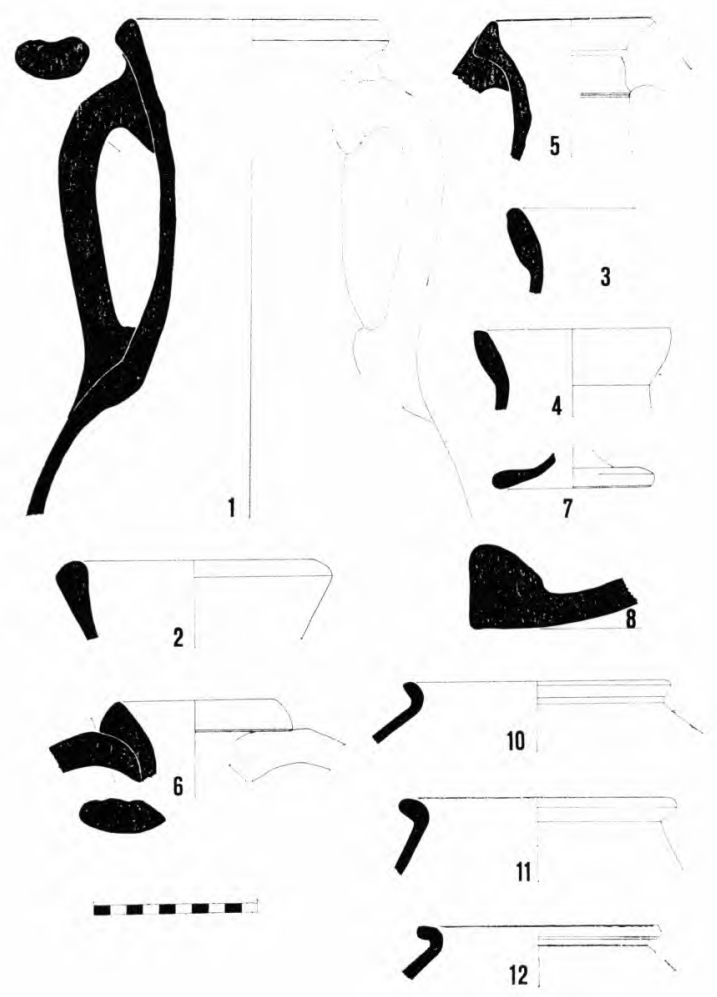




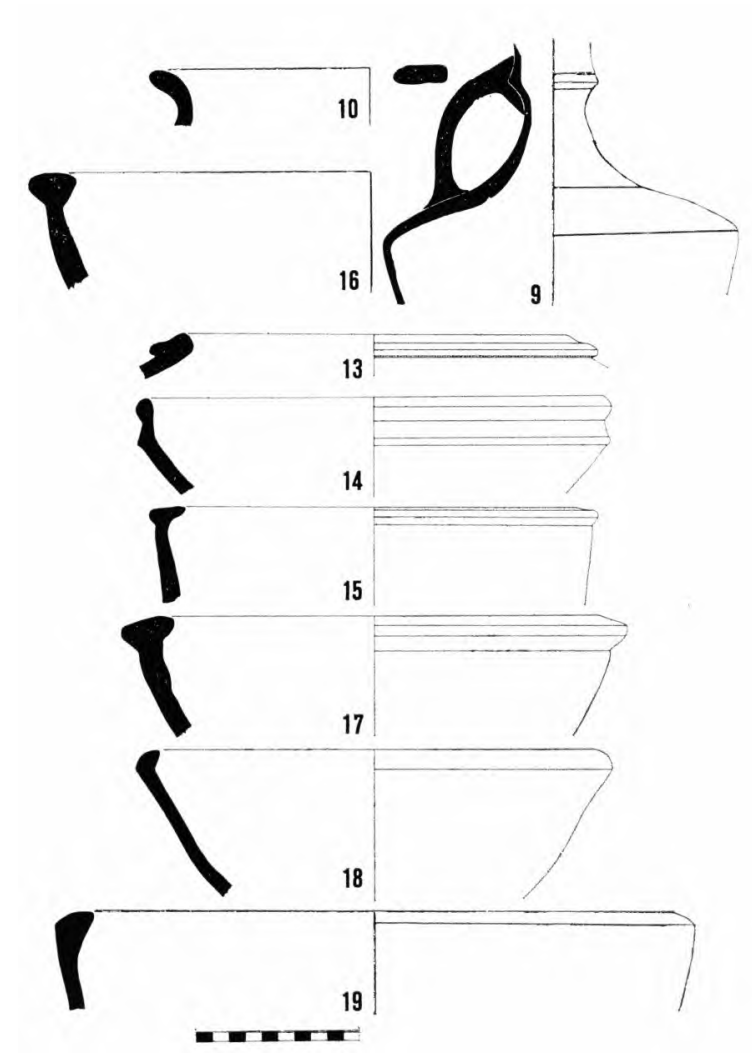


est. XIX

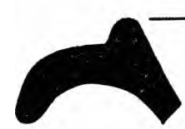

HI $/ \| \mid$
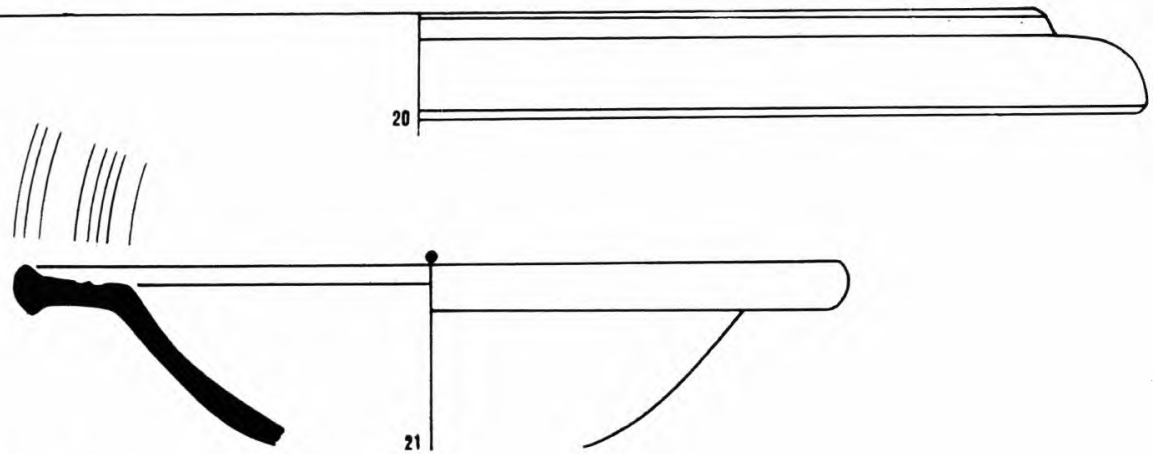

||.| |||| 
Est. XX
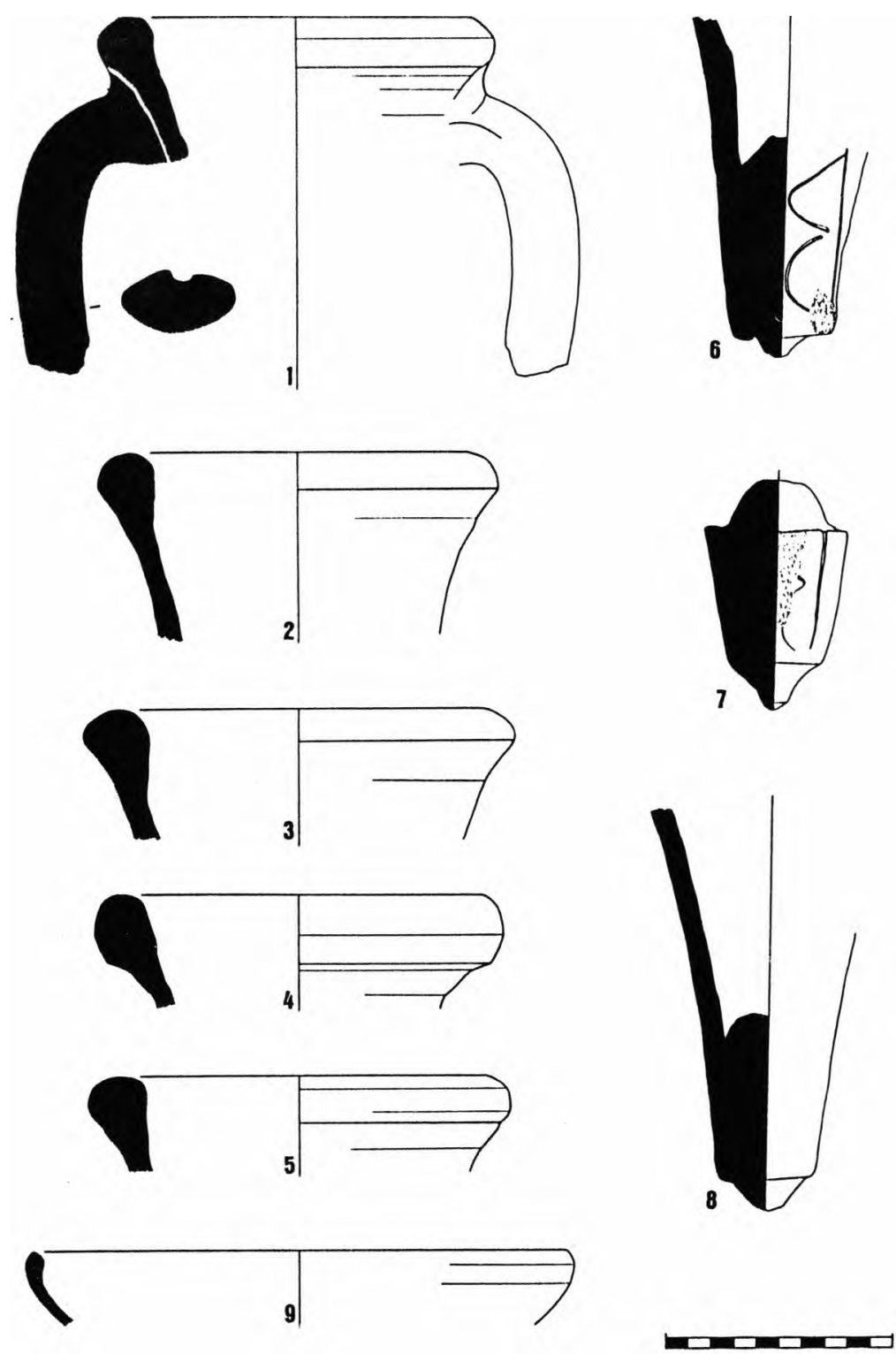


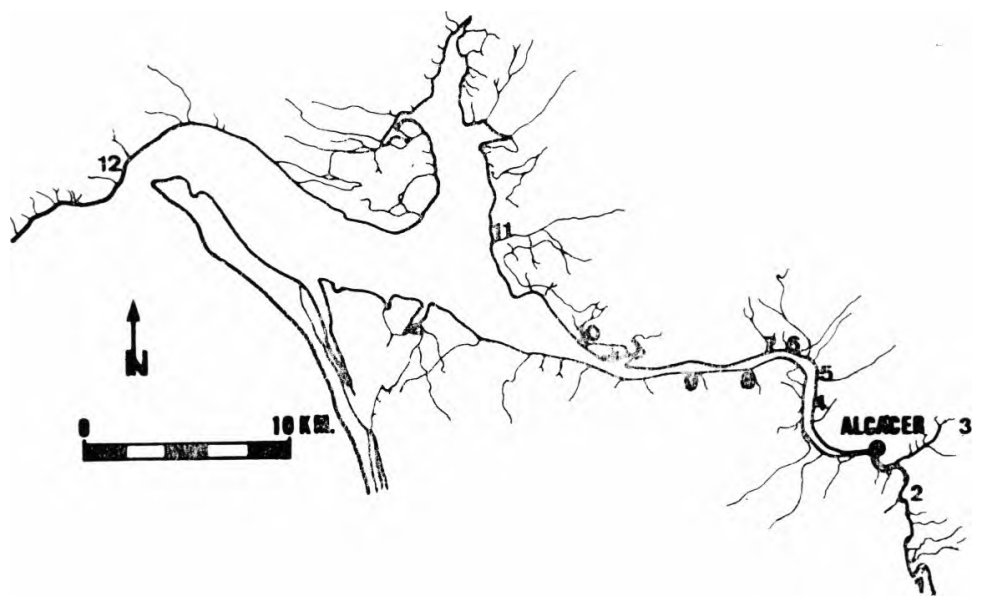

MAPA 1 - Localização de algumas estações do Baixo Sado: 1-Arapouca, 2- Barrosinha, 3 - Porto da Lama, 4 - Bugio I, 5 - Bugio IL 6 - Vale da Cepa, 7 - Enchurrasqueira, 8 - Batalha, 9 - Casa Novas, 10 - Abúl, 11 - Pinheiro, 12 - Comenda.

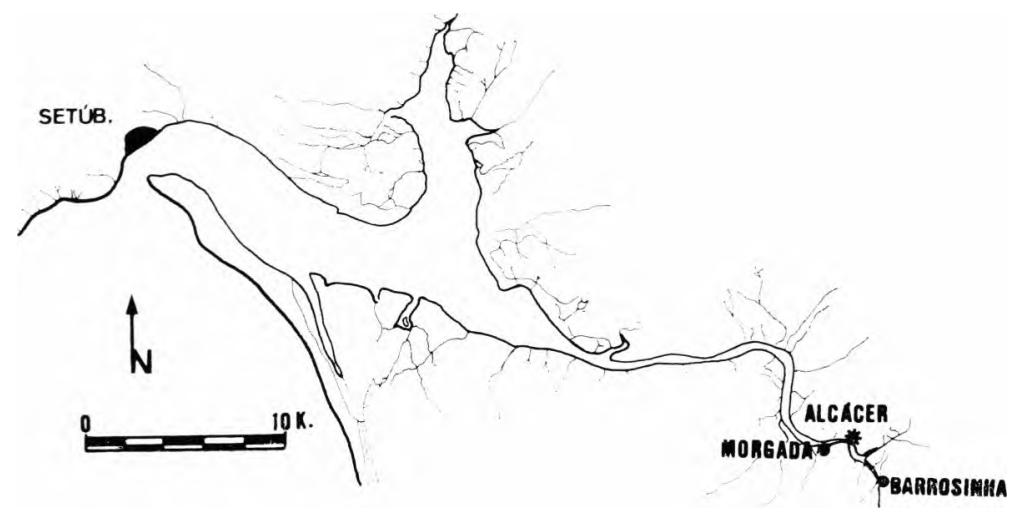

MAPA 2 - Localização da Morgada no curso inferior do Sado. 